\title{
High-throughput analysis of enzyme activities
}

by

\section{Guoxin Lu}

\begin{abstract}
A thesis submitted to the graduate faculty in partial fulfillment of the requirements for the degree of MASTER OF SCIENCE
\end{abstract}

Major: Analytical Chemistry

Program of Study Committee: Edward S. Yeung, Major Professor Robert S. Houk Yan Zhao

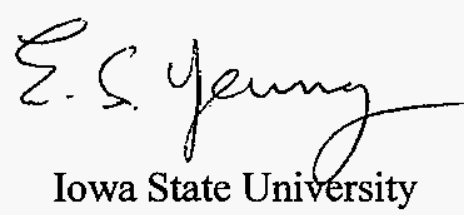

Ames, Iowa

Copyright (C) Guoxin Lu, 2007. All rights reserved. 
To Chengxiang and Anya 


\section{CHAPTER 1. GENERAL INTRODUCTION}

General Introduction

Dissertation Organization

References

CHAPTER 2. COMBINATORIAL SCREENING OF IMMOBILIZED ENZYME ON NYLON SCREEN BY MULTIPLEXED CAPILLARY SYSTEM

Introduction

5

Experimental Section

6

Results and Discussion

Conclusions

12

References

CHAPTER 3. HIGH-THROUGHPUT ENZYME KINETICS USING MICROARRAYS

$\begin{array}{ll}\text { Introduction } & 24\end{array}$

Experimental Section $\quad 26$

Results and Discussion $\quad 28$

$\begin{array}{ll}\text { Conclusions } & 34\end{array}$

$\begin{array}{ll}\text { References } & 35\end{array}$

CHAPTER 4. FLUORESENCE DETECTION OF ADENOSINE 5'DIPHOSPHATE

Introduction $\quad 45$

Experimental Section $\quad 47$

Results and Discussion $\quad 49$

Conclusions $\quad 51$

References $\quad 52$

$\begin{array}{lr}\text { GENERAL CONCLUSIONS } & 64\end{array}$

$\begin{array}{ll}\text { ACKNOWLEDGEMENTS } & 66\end{array}$ 


\section{5-T 2294}

1

\section{CHAPTER 1. GENERAL INTRODUCTION}

\section{General Introduction}

High-throughput screening (HTS) is an automated method, which allows quick analysis of activities of large amount of analysts. Recently, HTS techniques have become key tools in the fields of drug discovery ${ }^{1,2}$ and new catalyst discovery. 3,4

One of the most important advantages for HTS is miniaturization, which reduces the cost of reagents and also the amount of chemical waste. For example, 384-well or 1536-well microtiter plates have become standard in handling homogeneous assays with volume of as low as a few microliters. In heterogeneous assays, microarray printing allows facile handling of reagent solutions at nanoliter scale.

Modern genomic and proteomic studies have indicated up to 10,000 druggable targets in human bodies. Among these, about 500 targets have corresponding FDA-approved drugs, with about $28 \%$ of these targets being enzymes. ${ }^{5}$ For example, enzymes such as kinases, proteases, and cytochromes are important drug targets for treating a wide range of diseases including cancer, inflammatory, HIV and cardiovascular disorders. ${ }^{6-9}$ Protein kinases, because of their important signal transduction functions, have become one of most important types of targets for drug discoveries. ${ }^{6}$ Given the large numbers of potential targets, efficient analytical techniques to identify drugs for these targets become imminently critical in drug discoveries. Because of their unique chemo-, regio-, and stereo-specificity as well as their mild reaction conditions, enzymes are also important industrial catalysts in organic 
synthesis. ${ }^{10-11}$ HTS techniques are highly desirable in searching for the best conditions for enzyme reactions and for screening the activities of artificially modified biocatalysts.

In order to generate detectable signals, following assay techniques are widely used for HTS: fluorogenic substrate assay; ${ }^{12}$ immunoassay; ${ }^{13}$ bioluminescence assay; ${ }^{14}$ radioisotope labeling assay; ${ }^{15}$ and fluorescence polarization (FP) assay. ${ }^{16,17}$ All of these techniques need either modification of the substrates or the introduction of additional enzymes or tracers. The development of simple, fast, reliable, miniaturized, economical, quantitative, and environmentally friendly HTS techniques has been one of the most active forefronts in analytical chemistry, drug discovery, and chemical industry. My dissertation work is devoted to develop new HTS techniques to meet these goals.

\section{Dissertation Organization}

This dissertation begins with a general introduction. The following chapters are presented as three scientific manuscripts, each followed by references, tables and figures.

In Chapter 2, we have successfully imaged immobilized enzyme patterns using an in-house built multiplex capillary system. This extends previous studies in our group on high throughput imaging of metal electrodes and inorganic catalysts to biocatalysts. Our results indicate that this technique has the potential of screening combinatorial arrays of multiple catalysts, or imaging local variations in activities of a single catalyst.

In Chapter 3, we have developed an efficient, novel in-situ high throughput enzyme kinetics method. The enzymes are printed in microarray format on poly-l-lysine (PLL) coated glass slides by a micro-spotting robotic system. A scientific charge-coupled device (CCD) is used 
to monitor the reactions on-line through detecting the light intensity changes caused by the reaction products. Reactions on hundreds of enzyme spots could be efficiently monitored at the same time. The Michaelis constant $K_{m}$ obtained using this method is comparable to the one obtained from the homogenous solution.

$\mathrm{ADP}$ and $\mathrm{ATP}$ are critical ingredients in numerous biological systems. In Chapter 4, we carefully studied the fluorescence spectra of ADP and ATP. The fluorescence detection of $\mathrm{ADP}$ is potentially a direct and universal detection method for kinase inhibitor screening.

\section{References}

1. Kumar, R. A.; Clark, D. S. Curr. Opin. Chem. Biol. 2006, 10, 162-168.

2. Goddard, J.-P.; Reymond, J.-L. Curr. Opin. Biotechnol. 2004, 15, 314-322.

3. Bornscheuer, U. T. Angew. Chem., Int. Ed. 2003, 42, 3336-3337.

4. Pohna, B.; Gerlach, J.; Scheideler, M.; Katz, H.; Uray, M.; Bischof, H.; Klimant, I.; Schwab, H. J. Biotechnol. 2007, 129, 162-170.

5. Drews, J. Science, 2000, 287, 1960-1964.

6. Ashen, O.; Bomer, U. ChemBioChem 2005, 6, 481-490.

7. Noble, M.E.M.; Endicott, J. A.; Johnson, L. N. Science 2004, 303, 1800-1805.

8. Gillam, E.M.J. Clin. Exp. Pharm. Physiol. 2005, 32, 147-152.

9. Garrido, C.; Kroemer, G. Curr. Opin. Cell Biol. 2004, 16, 639-646.

10. Schoemaker, H. E.; Mink, D.; Wubbolts, M. Science 2003, 299, 1694-1697.

11. Schmid, A.; Dordick, J. S.; Hauer, B,; Kiener, A.; Wubbilts, M.; Witholt, B. Nature 2001, $409,258-268$. 
12. Kupcho, K.; Hsiao, K.; Bulleit, B.; Goueli, S. A. J. Biomol. Screening 2004, 9, 223-231.

13. Beasley, J. R.; McCoy, P. M.; Walker, T. L.; Dunn, D. A. Assay Drug. Dev. Tech. 2004, $2,141-151$.

14. Koresawa, M.; Okabe, T. Assay. Drug. Dev. Tech. 2004, 2, 153-160.

15. Houseman, B. T.; Huh, J. H.; Kron, S. J.; Mrksich, M. Nature Biotechnol. 2002, 20, 270274.

16. Turek-Etienne, T. C.; Lei, M.; Terracciano, J. S.; Langsdorf, E. F; Bryant, R. W.; Hart, R. F.; Horan, A. C. J. Biomol. Screening 2004, 9, 53-61.

17. Fowler, A.; Swift, D.; Longman, E.; Acornley, A.; Hemsley, P.; Murray, D.; Unitt, J.; Dale, I.; Sullivan, E.; Coldwell, M. Anal. Biochem. 2002, 308, 223-231. 


\section{CHAPTER 2. COMBINATORIAL SCREENING OF IMMOBILIZED ENZYME ON NYLON SCREEN BY MULTIPLEXED CAPILLARY SYSTEM}

\section{Introduction}

The completion of human genome indicates that there are up to 10,000 potential druggable targets. ${ }^{1}$ Among these potential targets, enzymes, such as kinases, proteases, and cytochromes are very important for treating a wide range of diseases including cancer, inflammatory, HIV and cardiovascular disorders. ${ }^{2-5}$ With the huge quantity of targets available, efficient analytical tools to identify drug targets and drugs becomes imminently critical in drug discoveries.

High-throughput screening (HTS) allows automated analysis of large amount of analytes in a short time. HTS techniques are highly demanded in the field of drug discovery ${ }^{6,7}$ and new catalyst discovery. ${ }^{8,9}$ Current HTS techniques for enzyme analysis include but not limited to: fluorogenic substrate assay; ${ }^{10}$ immunoassay; ${ }^{11}$ bioluminescence assay; ${ }^{12}$ radioisotope labeling; ${ }^{13} \mathrm{LC} / \mathrm{MS} ;{ }^{14}$ etc.

Multiplexed capillary electrophoresis (CE) has recently been developed as powerful HTS tool for DNA sequencing, protein separation, chiral separation, drug discoveries, etc. ${ }^{15-20}$ In situ catalyst surface imaging technique allows us to tell the local variations of immobilized catalyst or to screen multiple catalysts at once. In this chapter, we extend previous studies in our group on in situ imaging of metal electrodes ${ }^{21}$ and inorganic catalysts ${ }^{22,23}$ to biocatalysts 
using multiplexed capillary system. When using porous solid support for enzymes, lateral diffusion is negligible. Our results further prove that this technique has the ability to screen combinatorial array of multiple catalysts, and to image local variations in activities of one catalyst.

\section{Experimental Section}

Reagents and materials. $1 \mathrm{mg} / \mathrm{ml}$ Horseradish peroxidase (HRP) solution, $0.3 \mathrm{~g} / \mathrm{ml} 2,2^{\prime}-$ azino-bis(3-ethylbenzthiazoline-6-sulphonic acid) (ABTS) solution, $0.02 \%$ hydrogen peroxide $\left(\mathrm{H}_{2} \mathrm{O}_{2}\right)$ solution, one component 3,3',5,5'-Tetramethylbenzidine (TMB) membrane peroxidase substrate, $10 \%$ bovine serum albumin (BSA) blocking solution, and $20 \mathrm{X}$ wash solution concentrate, were purchased from Kirkegaard \& Perry Laboratories (Gaithersburg, Maryland). All solutions were diluted with Milli-Q (Millipore, Billerica, MA, USA) water as needed. Once diluted, the $1 \mathrm{X}$ working solution contains $0.002 \mathrm{M}$ imidazole buffered saline with $0.02 \%$ Tween 20 . Untreated nylon-66 screens were purchased from Small Parts (Miami Lakes, FL).

Instrumental setup. The multiplexed capillary system has been described before. ${ }^{21} \mathrm{~A}$ photograph of the experimental setup is shown in Figure1. Briefly, a total of 102 fused silica capillaries (75- $\mu \mathrm{m}$ i.d., $150-\mu \mathrm{m}$ o.d.; Polymicro Technologies Inc., Phoenix, AZ) with $60-\mathrm{cm}$ effective length and $90-\mathrm{cm}$ total length were packed side by side at the detection window. A tungsten lamp powered by a $12 \mathrm{~V}$ car battery is used as light source. The tungsten lamp was enclosed in a dark box with a $2.5-\mathrm{cm}$ by $1.5-\mathrm{cm}$ opening on the face that facing the detection window to eliminate straight light. In order to uniformly illuminate the detection window, two cylindrical lenses are used to expend the light. The transmitted light was then focused on 
a photodiode array (PDA) (model C5964-SPL01, Hamamatsu, Japan) using a quartz camera lens (Nikon, f.l. $=105 \mathrm{~mm}, \mathrm{f}=4.5$ ). A $405 \mathrm{~nm}$ interference filter is used to select the desired absorption wavelength. Data were collected using an in-house program written using LabView 6.0 (National Instruments, Austin, TX). In all experiments, gravity injection and flow was implemented by lowering the outlet vial $30-\mathrm{cm}$ below the inlet vial.

Imaging probe. A photograph of the imaging probe used in this study is shown in Figure 2. The fabrication of the imaging probe has been described before. ${ }^{21}$ The imaging probe has roughly round shape with approximately $1.7-\mathrm{mm}$ in diameter. In order to re-use the imaging probe and get good quality images, it is important to wash the capillaries after each use. The capillaries at the outlet end were grouped into 8 groups in PEEK tubing (Upchurch Scientific, Oak Harbor, WA). The grouped capillaries are then connected to a water pump through adaptors when wash is needed. During experiment, all 8 groups of capillaries were connected to one PEEK tube through an eight-port adaptor. This guarantees the outlet end could be put at the same level with the inlet end when needed.

Sample preparation and reactions. A piece of pulled fused silica capillary (outer diameter $\sim 30-\mu \mathrm{m}$ ) coupled with a $0.5-\mu \mathrm{l}$ syringe (Hamilton Company, Reno, NV) was used to apply the HRP solutions onto nylon screen. After air-drying the sample for one hour, the nylon screen was treated with $1 \%$ BSA solution for 5 min to cover any free spaces on the nylon screen. Then, the screen was washed in $1 \mathrm{X}$ wash solution three times with 5 min each time to remove any free HRP and BSA molecules. The concentration of HRP used was $1 \mathrm{mg} / \mathrm{ml}$ unless otherwise noted. The sample screen was ready for use after the treatment. 
ABTS is used as substrate for the detection of immobilized HRP. The oxidation of ABTS by hydrogen peroxide forms a green soluble product with absorption maximum at $405-415 \mathrm{~nm}$. During the experiment, green products generated by HRP molecules are taken to the adjacent capillaries immediately for detection.

As a comparison, after the experiment, the sample nylon screen was removed and "stained" using TMB membrane substrate. The TMB membrane substrate formed blue precipitates after the oxidation. The precipitates deposited on the HRP sites, thus showed the pattern of HRP on nylon screen. The HRP patterns were recorded by a digital camera under a stereomicroscope.

Sample injection. An illustration of the reaction chamber is shown in Figure 3. The chamber contains two major parts: chamber body and a cover piece. The chamber body has a 5-mm by $15-\mathrm{mm}$ channel on it. The cover piece has two 5-mm diameter through holes, which located right above the two ends of the body channel. During the experiment, the sample screen was fixed in between the chamber body and the cover piece. Care was taken to make sure the HRP pattern is located in the left hole and the imaging probe was slightly touching the HRP pattern. Before the enzyme reaction began, the outlet end of the capillary bundle was put at the same height level with the inlet end, so that solution in the capillaries would not flow. The reaction started by quickly adding substrate solution into the reaction chamber through the right hole on the cover. At the same time, the outlet end of the capillaries was lowered by about $30-\mathrm{cm}$ to start sampling by gravity flow. Sample injection time was 8 seconds for all the experiments. After sampling, the imaging probe was removed from the reaction chamber and was put into buffer vial. 
A reference solution containing absorbing species was injected into all the capillaries $3 \mathrm{~min}$ before the enzyme reaction starts. This reference peak was used to tell whether a capillary was in un-blocked condition. It was also used as reference for calibrating the product peak in the same capillary. In our experiments, freshly prepared green oxidation product of ABTS was used as reference.

\section{Results and Discussion}

Identification of imaging probe capillaries. The imaging probe used in our study contains 102 capillaries. The correlation of a particular capillary at the probe end and at the detection window was determined through injecting water to that capillary while observing the imaging probe under a microscope. More capillaries can be used to increase the imaging probe area, or improve the image resolution, i.e., decrease the outer diameter of capillary. Theoretically, for $2^{\mathrm{n}}$ capillaries, spatial correlations of all capillaries can be determined from only $n$ times of water injection, each time with half of the total capillaries injected with water. This can be easily understood as follows: At the detection window, we assign each capillary a binary code according to its position. For $2^{\mathrm{n}}$ capillaries, we need $n$ digits, from $(00 \ldots 0)_{\mathrm{n}}$ to $(11 \ldots 1)_{n}$. For each digit, half of the capillaries will be 1 , while the other half will be 0 . Then, for each digit, inject water to the capillaries if the assigned number is1, and take the result from the imaging probe. Repeat this process for $n$ times, each capillary on the imaging probe will get a unique $n$-digit binary code, which will be related to the assigned one on the detection window. Using this method, 1024 capillaries can be identified in only 10 steps.

Sampling. Enzyme catalyzed reaction is very fast. Reaction starts immediately after the contact of the enzyme molecules and the substrate solution. In order to minimize lateral 
diffusion and get highest imaging resolution, reaction product must be removed into the adjacent capillaries right away, i.e., sampling process must start simultaneously with the contact of substrate solution and enzyme molecules. The position of the imaging probe is also very important. The probe needs to be very close to, as well as perpendicular to, the surface to be imaged.

Solid support of enzymes. We have examined both non-porous solid support and porous solid support for HRPs. When using non-porous support, in our case, glass, images with satisfactory resolution could not be obtained. This can be explained in Figure 4. When using non-porous support, the sampling process will form a lateral flow surround the imaging probe. Thus, the lateral resolution of image cannot be guaranteed. When using porous support, as the imaging probe is close enough to the catalytic surface, the sampling process will form a vertical flow across the porous surface to the imaging probe. This vertical flow will bring the products on the surface directly up to the adjacent capillaries with minimal lateral diffusion. The nylon mesh used in this study has mesh opening of $30-\mu \mathrm{m}$, and thread diameter of $35-\mu \mathrm{m}$. The mesh size is big enough for the substrate solutions to pass freely.

Treatment of capillary bundle. Since the inner diameter of the capillary is very narrow, capillaries are easily blocked by dust particles or impurities in sample solutions. In order to keep the capillaries in good and clean conditions, the capillaries need to be washed for 15 min with Milli-Q water before and after each use. Also, the capillaries need to be washed by high-pressure water for $30 \mathrm{~min}$ every day to un-clog any blocked capillaries. Before each experiment, the imaging probe need to be treated with boiling water for 5 min to kill any HRP molecules accidentally stuck to the probe surface from previous experiment. 
Imaging results. Three different patterns of immobilized HRPs were imaged in our experiment. The reconstructed images are shown in Figure 5(a) through Figure 7(a). In these images, each circle represents one capillary. The number in each circle is the sequential number of that capillary on the detection window. The outer diameter of each capillary is about $165-\mu \mathrm{m}$ including the gaps in between capillaries. In all cases, ratio of the product peak area divided by the reference peak area in the same capillary was plotted. The darker the circle, the more the products were detected in that capillary. This calculation was done to correct for any differences in injection efficiency between capillaries. The variation between capillaries could result from the variations in capillary inlet shapes, and/or impurity particles in some capillaries. In all cases, a black cross in a circle means that capillary was blocked during that experiment, i.e., no reference peak came out in that capillary.

The corresponding TMB stained HRP patterns are shown in Figure 5(b) through Figure 7(b). The relative positions of imaging probe to the HRP patterns are also shown in these Figures. The nylon thread can be used as rulers to precisely tell the dimensions of the HRP patterns. In Figure 5(b), the HRP spot size is $0.29 \mathrm{~mm}$ by $0.42 \mathrm{~mm}$, which equals to about 2 by 3 capillaries as shown in Figure 5(a). In Figure 6(b), the HRP line size is about $0.36 \mathrm{~mm}$ in width and $1.56 \mathrm{~mm}$ in length. The line width is slightly more than double the capillary outer diameter. The reconstructed image in Figure 6(a) shows the same HRP line occupies three closely packed capillary lines. Among the three capillary lines, the middle line has higher product concentration then that of the two outer lines. This means capillaries in the two outer lines were only covered partially with HRPs, while the capillaries in the middle line are fully covered with HRPs during the experiment. 
Quantitation. The calibrated product peak areas in Figure 7(a) are listed in Table 1. The capillaries are grouped according to the HRP spots they belong. The initial concentrations of HRP for all of the four spots are the same. The actual HRP spot areas calculated from Figure $7(b)$, and the results of total product peak area per unit spot area of each HRP spot are listed in Table 2. These results show very good quantitative accuracy with standard deviation of $5 \%$. The results of average product peak area per capillary for each HRP spot are also listed in Table 2. These results show higher standard deviation, about $23 \%$. This is because the maximum resolution of the imaging probe is restricted by the capillary size. Since the HRP spots are relatively small, the inlet ends of same capillaries are only covered partially by the enzyme.

\section{Conclusions}

In this work, we have successfully imaged immobilized enzyme patterns using an in-house built multiplex capillary system. This extends previous studies in our group on in situ imaging of metal electrodes and inorganic catalysts to biocatalysts. When using porous solid support for enzymes, lateral diffusion is negligible. The image resolution is determined by the outer size of the capillary. Smaller capillary can be used to get finer image. Quantitative detections are achieved. Our results further prove that this technique has the ability to screen combinatorial array of multiple catalysts, and to image local variations in activities of one catalyst.

\section{Acknowledgments}


We thank Michael Christodoulou for making the capillary imaging probe. E.S.Y. thanks the Robert Allen Wright Endowment for Excellence for support. The Ames Laboratory is operated for the US Department of Energy by lowa State University under Contract No. W7405-Eng-82. This work was supported by the Director of Science, Office of Basic Energy Sciences, Division of Chemical Sciences and by the National Institutes of Health.

\section{References}

1. Drews, J. Science 2000, 287, 1960-1964.

2. Ashen, O.; Bomer, U. ChemBioChem 2005, 6, 481-490.

3. Noble, M.E.M.; Endicott, J. A.; Johnson, L. N. Science 2004, 303, 1800-1805.

4. Gillam, E.M.J. Clin. Exp. Pharm. Physiol. 2005, 32, 147-152.

5. Garrido, C.; Kroemer, G. Curr. Opin. Cell Biol. 2004, 16, 639-646.

6. Kumar, R. A.; Clark, D. S. Curr. Opin. Chem. Biol. 2006, 10, 162-168.

7. Goddard, J.-P.; Reymond, J.-L. Curr. Opin. Biotechnol. 2004, 15, 314-322.

8. Bornscheuer, U. T. Angew. Chem., Int. Ed. 2003, 42, 3336-3337.

9. Pohna, B.; Gerlach, J.; Scheideler, M.; Katz, H.; Uray, M.; Bischof, H.; Klimant, I.; Schwab, H. J. Biotechnol. 2007, 129, 162-170.

10. Kupcho, K.; Hsiao, K.; Bulleit, B.; Goueli, S. A. J. Biomol. Screening 2004, 9, 223-231.

11. Beasley, J. R.; McCoy, P. M.; Walker, T. L.; Dunn, D. A. Assay Drug Dev. Technol. 2004, 2, 141-151.

12. Koresawa, M.; Okabe, T. Assay Drug Dev. Technol. 2004, 2, 153-160.

13. Houseman, B. T.; Huh, J. H.; Kron, S. J.; Mrksich, M. Nature Biotechnol. 2002, 20, 270274. 
14. Peng, S. X.; Barbone, A. G.; Ritchie, D. M. Rapid Commun. Mass Spectrom. 2003, 17, $509-518$.

15. Gong, X.; Yeung, E. S. Anal. Chem. 1999, 71, 4989-4996.

16. Pang, H.; Kenseth, J.; Coldiron, S. Drug Discovery Today 2004, 9, 1072-1080.

17. Ma, L.; Gong, X.; Yeung, E. S. Anal. Chem. 2000, 72, 3383-3387.

18. Zhong, W.; Yeung, E. S. J. Chromatogr. A. 2002, 960, 229-239.

19. Zhong. W.; Yeung, E. S. Electrophoresis 2002, 23, 2996-3005.

20. He, Y.; Yeung, E. S. Electrophoresis 2003, 24, 101-108.

21. Christodoulou, M.; Yeung, E. S. Anal. Chem. 2002, 74, 5414-5419.

22. Su, H.; Yeung, E. S. J. Am. Chem. Soc. 1999, 394, 350-353.

23. Su. H.; Hou, Y.; Houk, R. S.; Schrader, G. L.; Yeung, E. S. Anal. Chem. 2001, 73, 44344440. 
Table 1. Calibrated product peak areas of capillaries in Figure 7(a)

\begin{tabular}{|c|c|c|}
\hline HRP Spot \# & $\begin{array}{l}\text { Capillary } \\
\text { Sequence \# }\end{array}$ & $\begin{array}{c}\text { Calibrated Product } \\
\text { Peak Area } \\
\end{array}$ \\
\hline \multirow{6}{*}{ Spot-1 } & 86 & 1.16 \\
\hline & 74 & 1.09 \\
\hline & 76 & 0.91 \\
\hline & 97 & 0.50 \\
\hline & 68 & 0.48 \\
\hline & 89 & 0.37 \\
\hline \multirow{7}{*}{ Spot-2 } & 52 & 1.03 \\
\hline & 62 & 0.79 \\
\hline & 66 & 0.87 \\
\hline & 61 & 0.70 \\
\hline & 64 & 0.28 \\
\hline & 34 & 0.26 \\
\hline & 65 & 0.21 \\
\hline \multirow{4}{*}{ Spot-3 } & 14 & 1.72 \\
\hline & 18 & 0.54 \\
\hline & 44 & 0.35 \\
\hline & 38 & 0.32 \\
\hline \multirow{4}{*}{ Spot-4 } & 17 & 1.61 \\
\hline & 15 & 1.54 \\
\hline & 16 & 0.73 \\
\hline & 21 & 0.16 \\
\hline
\end{tabular}


Table 2. Quantitative results of HRP spots in Figure 7.

\begin{tabular}{|c|c|c|c|c|c|}
\hline $\begin{array}{c}\text { HRP } \\
\text { Spot \# }\end{array}$ & $\begin{array}{c}\text { Total Calibrated } \\
\text { Product Peak } \\
\text { Area } \\
\text { (A) }\end{array}$ & $\begin{array}{c}\text { Spot Area } \\
\text { from Figure } \\
\mathbf{7 ( b )} \\
\left.\text { (B) } \mathbf{( m m}^{2}\right)\end{array}$ & $\begin{array}{c}\text { Results of } \\
\mathbf{A} / \mathbf{B} \\
\text { (unit/mm }\end{array}$ & $\begin{array}{c}\text { Total \# of } \\
\text { Capillaries } \\
\text { Containing } \\
\text { Products } \\
\text { (C) }\end{array}$ & $\begin{array}{c}\text { Results of } \\
\text { A/C } \\
\text { (unit/capillary) }\end{array}$ \\
\hline Spot-1 & 4.51 & 16.3 & 0.28 & 6 & 0.75 \\
\hline Spot-2 & 4.14 & 13.7 & 0.30 & 7 & 0.59 \\
\hline Spot-3 & 2.93 & 10.5 & 0.28 & 4 & 0.73 \\
\hline Spot-4 & 4.04 & 15.2 & 0.27 & 4 & 1.01 \\
\hline
\end{tabular}




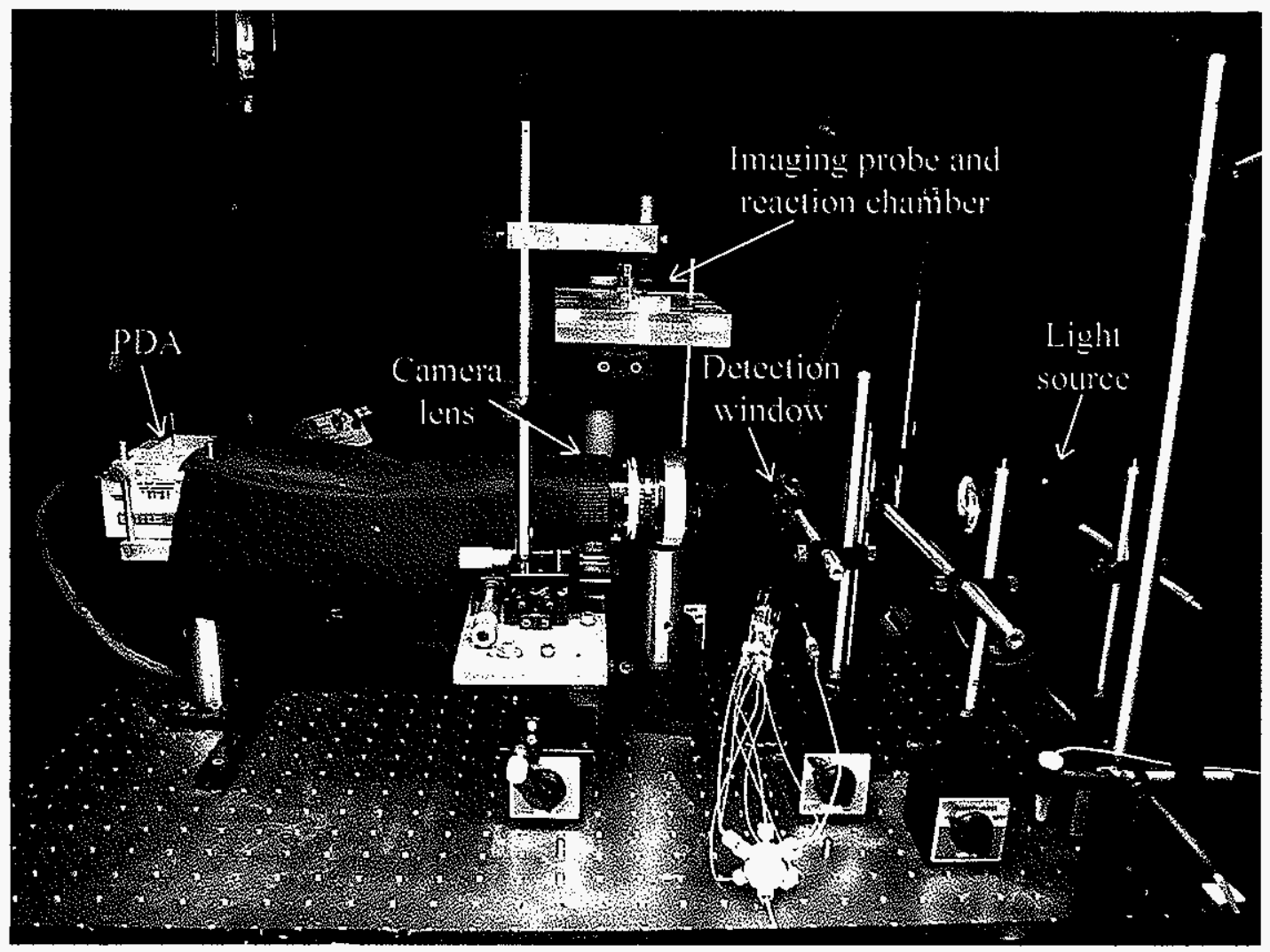

Figure 1. Photograph of the experimental setup. 


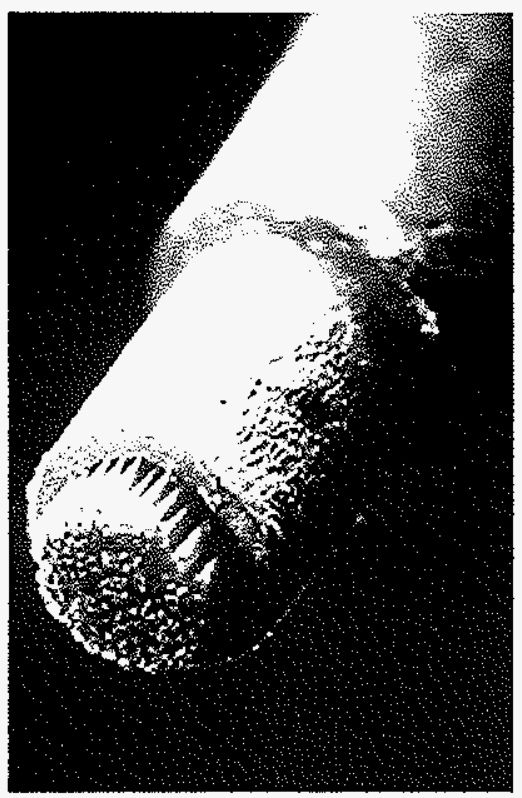

Figure 2. Photograph of the imaging probe. 


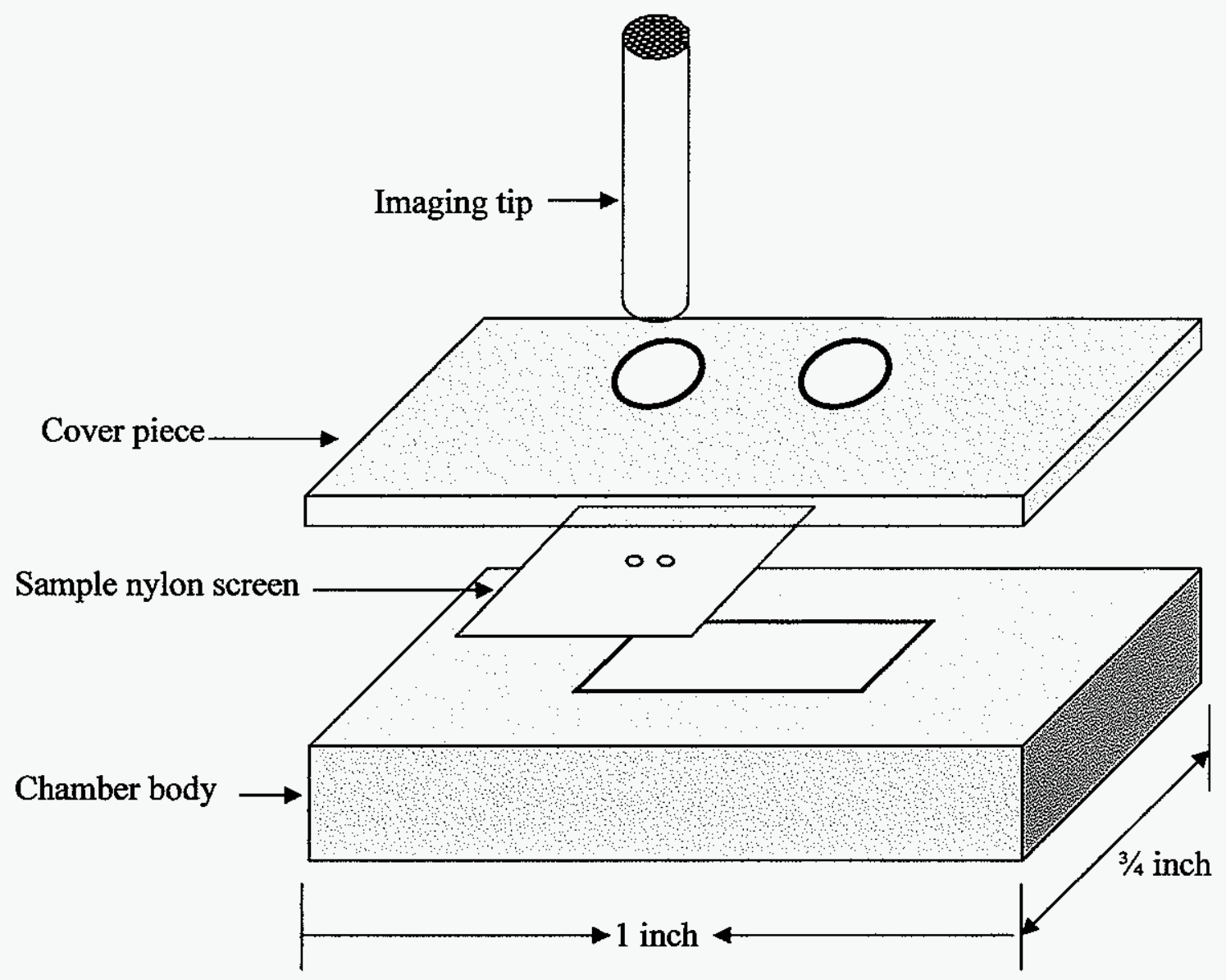

Figure 3. Illustration of the reaction chamber. 


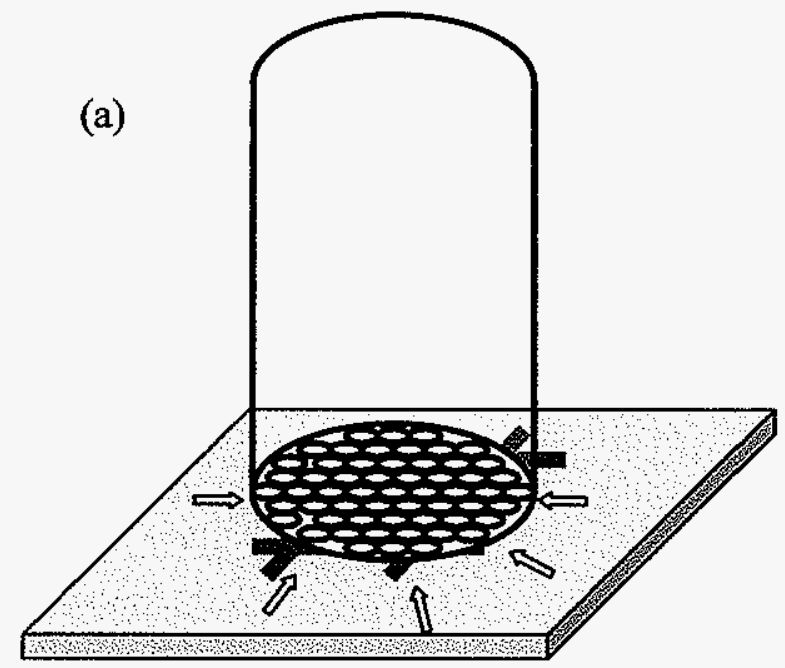

(b)

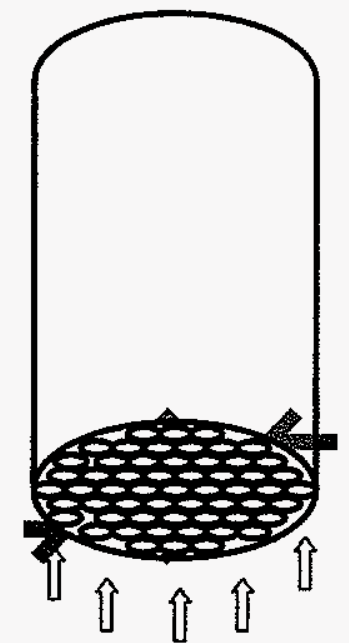

Figure 4. Illustrations of solution flow at the imaging probe in the case of (a) non-porous solid support; (b) porous solid support for immobilized enzymes. The red lines stand for the enzyme pattern. Arrows indicate the flow direction. 


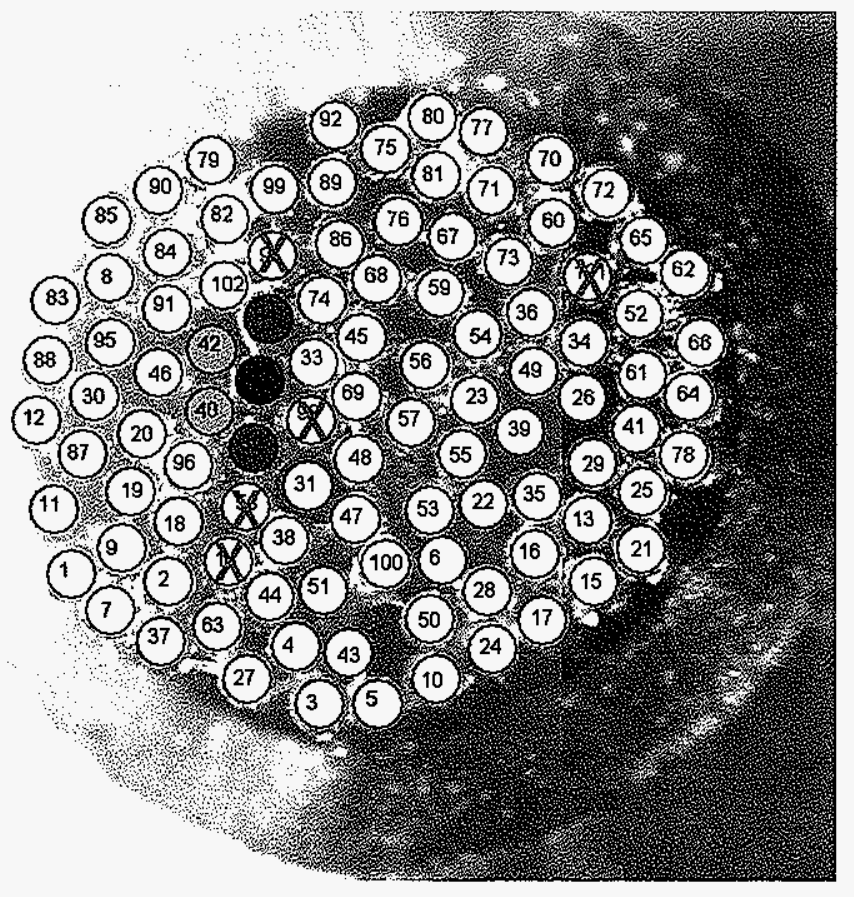

(a)

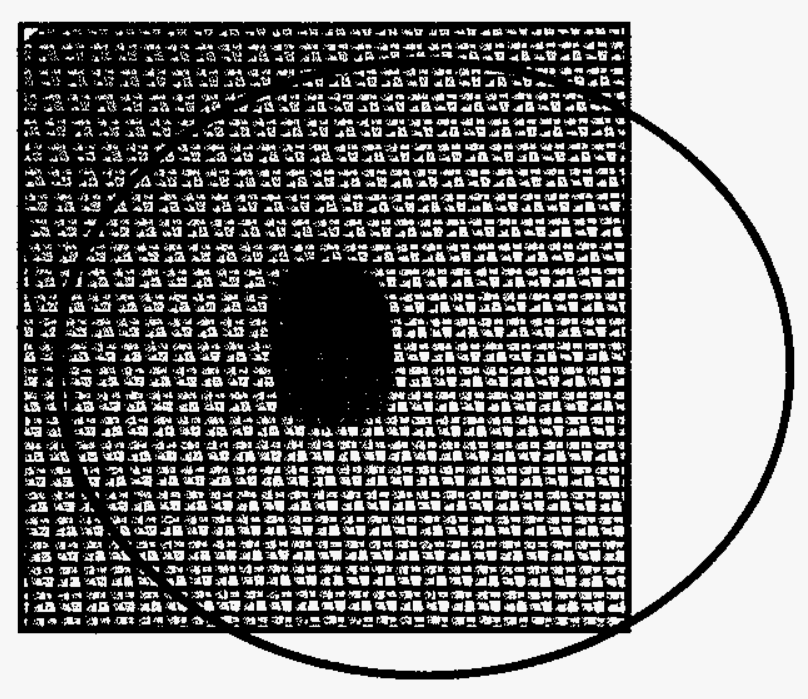

(b)

Figure 5. (a) Reconstructed image of an HRP dot; (b) TMB stained image of the same HRP dot. The black circle in (b) shows the relative position and size of the imaging probe. 


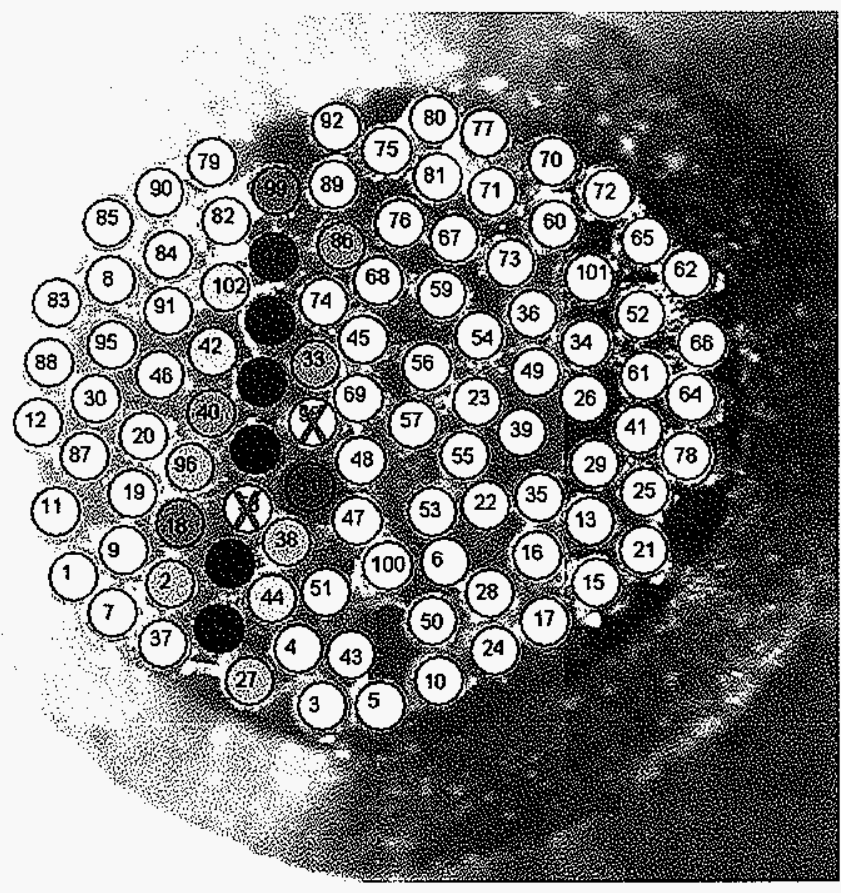

(a)

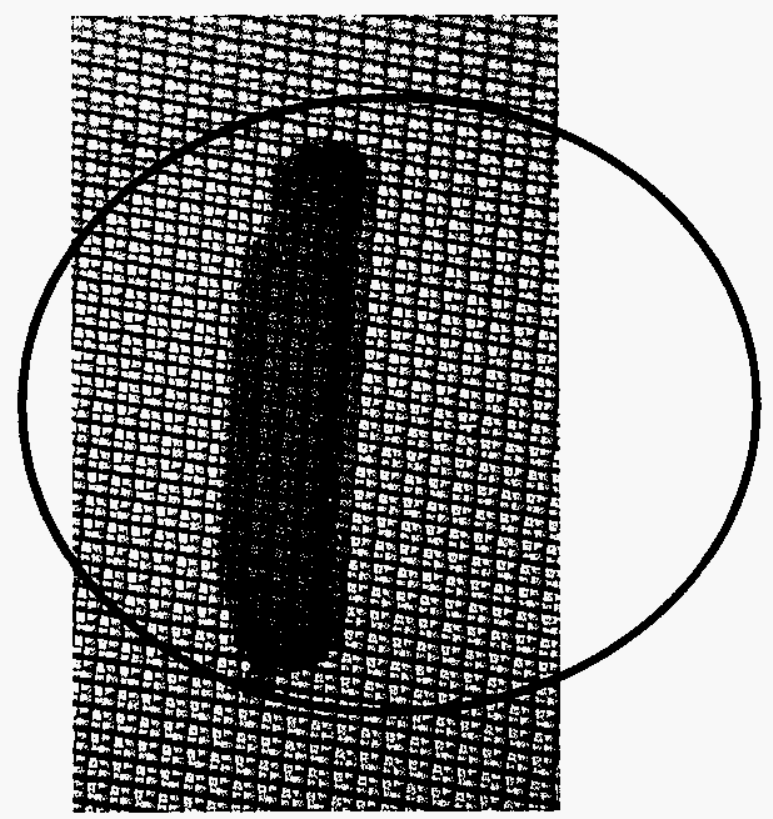

(b)

Figure 6. (a) Reconstructed image of an HRP line; (b) TMB stained image of the same HRP line. The black circle in (b) shows the relative position and size of the imaging probe. 


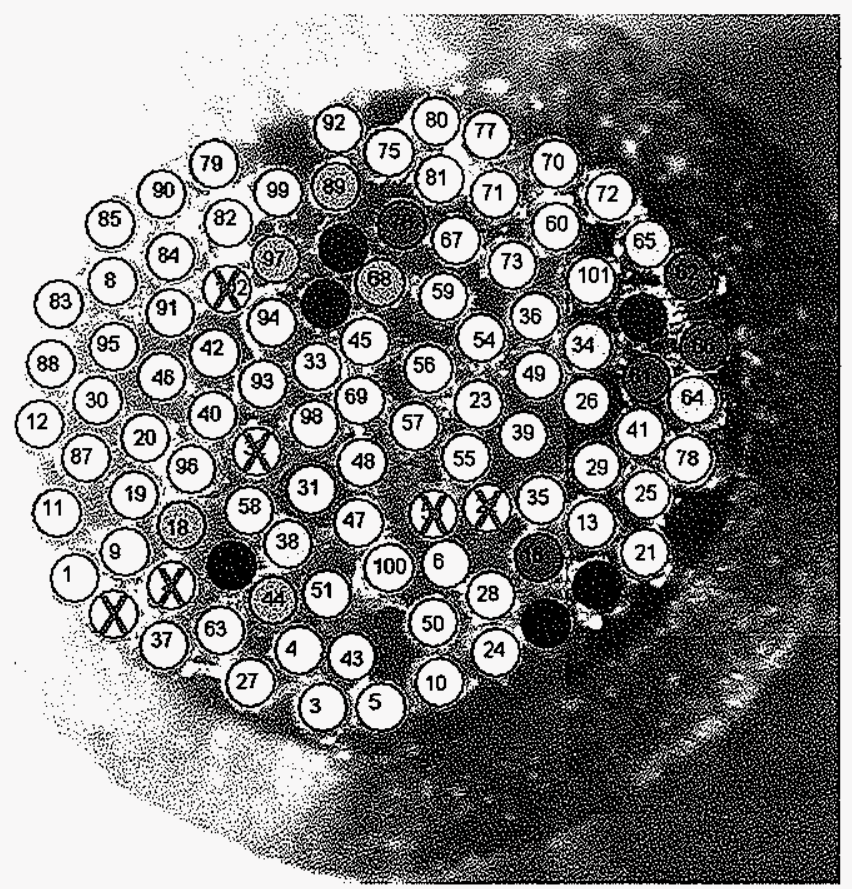

(a)

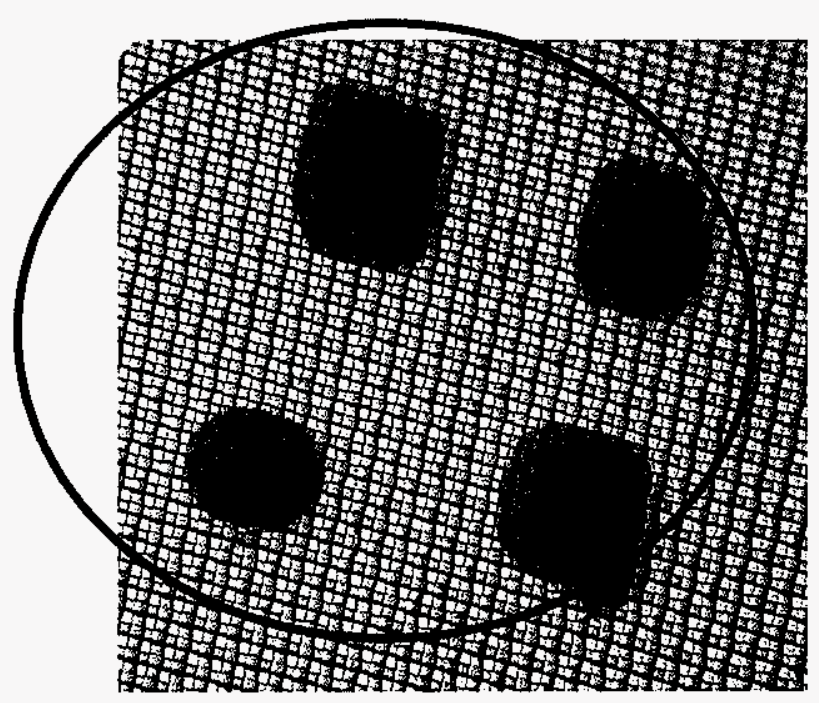

(b)

Figure 7. (a) Reconstructed image of four HRP spots; (b) TMB stained image of the same four HRP spots. The black circle in (b) shows the relative position and size of the imaging probe. 


\section{CHAPTER 3. HIGH-THROUGHPUT ENZYME KINETICS USING MICROARRAYS}

\section{Introduction}

The study of enzyme activity and kinetics is an important part of current proteomics research because of its diverse applications in the areas such as drug discovery, biochemical analysis, and optimization of enzymatic functions. Many of these applications call for high-throughput operation as well as minimal consumption of the precious samples. Therefore, the development of high-throughput technique for enzyme kinetics study using miniaturized reaction systems is highly desirable.

Immobilized enzymes have the advantages of reusability over their soluble counterparts. Several kinetic studies of immobilized enzymes in microfluidic systems have been reported. 1,2 Only microliter scale of substrate solutions were used in these studies. However, the microfluidic systems are rather complicated to manufacture and the detection throughput in these systems is limited. Protein microarrays have great potential to bring high-throughput assays into the miniaturized scale and represent one of the most powerful techniques developed recently in combinatorial drug discovery. 3,4 So far, such measurements are difficult to be quantitative and do not provide information about enzyme kinetics.

Only a few developments on high-throughput kinetic studies have appeared in the past few

years. Houseman et al..$^{5}$ developed a promising method for quantitative evaluation of protein 
kinase activity as following: at first, the glass slide was covered by a self-assembled monolayer containing peptide ligands; then, the kinase solutions containing $\left[\gamma-{ }^{32} \mathrm{P}\right] \mathrm{ATP}$ were spotted onto the peptide ligands on the slide; finally, quantification was made possible by phosphorimager analysis after incubation. Eppinger et al.6,7 developed another method for enzyme kinetics study by using fluorescence scanning on enzyme microarrays. In their case, many identical enzyme subarrays were printed on a slide, and then each subarray was incubated at one substrate concentration for a fixed reaction time. A fluorescently tagged affinity label (FAL) was used as the substrate, which was designed to covalently bind to the microarrayed enzyme spot after reaction. The kinetic constants were then obtained through analysis of the fluorescence data on each subarray after incubation. Both of the above methods require the formation of covalent bonds between the fluorescent or radioisotope labels and the immobilized analyte. Thus one enzyme subarray can be used only once in one reaction for the kinetics study.

Herein we demonstrate a simple high-throughput enzyme kinetics study using absorption monitoring. Horseradish peroxidases (HRPs) were immobilized on a poly-1-lysine (PLL) coated glass slide in a microarray format through electrostatic interactions. Real time kinetics of the HRP-catalyzed reaction between hydrogen peroxide $\left(\mathrm{H}_{2} \mathrm{O}_{2}\right)$ and $3,3^{\prime}, 5,5^{\prime}-$ tetramethylbenzidine (TMB) on the microarray was monitored by a CCD. Since the reaction product can be easily washed away, one enzyme array can be used multiple times for different experiments. The method reported here capitalizes on the fundamental advantages of using microarray-based technologies, and allows high-throughput profiling of different enzymes under a variety of conditions such as different substrates, different buffer $\mathrm{pH}$, etc. It 
may provide a useful tool for future research in proteomics, large-scale enzymology and drug discovery.

\section{Experimental section}

Reagents. TMB, N,N-dimethylformamide (DMF), and $30 \% \mathrm{H}_{2} \mathrm{O}_{2}$ were purchased from Sigma (St. Louis, MO, USA); dipotassium hydrogen phosphate $\left(\mathrm{K}_{2} \mathrm{HPO}_{4}\right)$, citric acid and potassium chloride $(\mathrm{KCl})$ were purchased from Fisher Scientific (Fair Lawn, NJ, USA). 10x BSA solution and 20x ELISA wash solution were purchased from KPL, Inc. (Gaithersburg, MD, USA). All salts used in this research were analytical grade. A series of Mcllvaine citrate-phosphate (C-P) buffers ${ }^{8}$ with ionic strength of $\mathrm{I}=0.5 \mathrm{M}$ and $\mathrm{I}=0.05 \mathrm{M}$ were prepared with $18 \mathrm{M} \Omega \cdot \mathrm{cm}$ Milli-Q (Millipore, Billerica, MA, USA) water. The buffer pHs were measured by an Orion $720 \mathrm{~A} \mathrm{pH}$ meter. The substrate solution was prepared by mixing $0.1 \mathrm{ml}$ of $0.5 \mathrm{M}$ citrate-phosphate buffer, $0.1 \mathrm{ml}$ of $12 \mathrm{mM} \mathrm{H}_{2} \mathrm{O}_{2}, 0.7 \mathrm{ml}$ of Milli-Q water, and $0.1 \mathrm{ml}$ of various concentrations of TMB solutions in DMF. A typical substrate solution in $0.05 \mathrm{M}$ citrate-phosphate buffer contained $10 \% \mathrm{DMF}, 1.2 \mathrm{mM} \mathrm{H}_{2} \mathrm{O}_{2}$, and $0.05 \sim 2.00 \mathrm{mM}$ TMB with a final $\mathrm{pH}$ of 5.1 .

Enzymes. Horseradish peroxidase type II (HRP-II, specific activity $=150-250$ units $/ \mathrm{mg}$ ) and horseradish peroxidase type VI-A (HRP-VIA, specific activity $=250-330 \mathrm{units} / \mathrm{mg})$ were purchased from Sigma. The stock solutions of peroxidases were prepared in water, and then diluted to the desired molar concentrations with $0.05 \mathrm{M} \mathrm{pH}$ 7.4 C-P buffer. The molar concentrations of the stock peroxidase solutions were determined spectrophotometrically with a Cary 300 Scan UV-visible spectrophotometer using molar coefficient of absorption of 
$102,000 \mathrm{M}^{-1} \mathrm{~cm}^{-1}$ at $\lambda=403 \mathrm{~nm} .{ }^{9}$ The final concentrations of HRPs used in this study are $3.0,3.25,3.5,4.0,5.0$, and $7.0 \mu \mathrm{M}$.

Enzyme immobilization. The enzyme microarrays were printed on PLL coated glass slides (Erie Scientific, Portsmouth, NH, USA) by using a contact micro-spotting robotic system, PIXSYS 5500 (Cartesian Technologies, Inc., Irvine, CA, USA). The average size of the spots was $165 \mu \mathrm{m}$ with a center-to-center distance of $280 \mu \mathrm{m}$. The micro spotting pin delivers about $1.5 \mathrm{~nL}$ of solution to each spot. The concentrations of the enzyme printing solutions were from $3.0 \mu \mathrm{M}$ to $7.0 \mu \mathrm{M}$. Printed slides were incubated for about $30 \mathrm{~min}$ at room temperature. They can be stored at $4{ }^{\circ} \mathrm{C}$ for up to $48 \mathrm{~h}$ without significant loss of enzymatic activities.

Reaction chamber. The glass slide is covered by a CoverWell perfusion chamber gasket (Invitrogen Corporation, Carlsbad, CA, USA) to form the reaction chambers (Fig 1a). Each chamber covers an area of about $13 \times 6 \mathrm{~mm}^{2}$. The enzyme array, about $1.7 \times 2.8 \mathrm{~mm}^{2}$, is located in the middle of the chamber. The chamber volume is about $70 \mu \mathrm{L}$ with a thickness of $500 \mu \mathrm{m}$. There are two holes on top of the chamber working as inlet and outlet. A micropipette is used to add and remove solutions.

Detection system. The detection system and illumination components are illustrated in Fig. 1b. A scientific-grade charge-coupled device (CCD) camera (Photometrics, Ltd., Tucson, AZ, USA) was used as the detector. The camera system includes a mechanical shutter that controls the exposure time. A personal computer with Winview/32 software (Roper Scientific, Princeton, NJ, USA) is used to control the CCD camera and the shutter. The CCD was 
cooled to $-37^{\circ} \mathrm{C}$ to decrease dark current. A $10 \times$ plano objective lens (Mitutoyo, Japan) was attached to the camera system. A 1" $650 \mathrm{~nm}$ bandpass filter with $10 \mathrm{~nm}$ bandwidth is placed in between the objective lens and the CCD camera to eliminate any unwanted light from the light source. The sample plate was illuminated with a red 12V LED light (Super Bright LEDs, Inc., St. Louis, MO, USA). A piece of frosted glass and a convex lens were placed close to the LED to generate more uniform light. A three-dimensional translational stage was connected to the sample holder to adjust sample position and to focus the light. The whole setup was enclosed in a dark box. The total imaging area was about $4.7 \times 4.7 \mathrm{~mm}^{2}$ for a full CCD chip, which corresponded to a $17 \times 17$ spots array. In the study presented here, only a part of the CCD chip was used to monitor an area of $1.9 \times 3.1 \mathrm{~mm}^{2}$.

\section{Results and discussion}

Horseradish peroxidase and TMB. Oxidase enzymes, particularly HRPs, are used in a wide variety of bioassays such as enzyme-linked immunosorbent assay (ELISA), immunoblotting, immunohistochemistry, etc. Thus, we chose HRP to demonstrate this high-throughput enzyme kinetics approach. In the presence of $\mathrm{HRP}, \mathrm{TMB}$ reacts with $\mathrm{H}_{2} \mathrm{O}_{2}$ at a 2:1 ratio to produce a blue-colored radical cation $\mathrm{TMB}^{+\bullet}$ (Figure 2$),{ }^{10}$ which has a maximum absorption coefficient of $39,000 \mathrm{M}^{-1} \mathrm{~cm}^{-1}$ at $\lambda=652 \mathrm{~nm} .{ }^{11}$

Sample preparation and detection. The amine groups on the poly-l-lysine (PLL) surface can be positively charged at $\mathrm{pH}<10$. Negatively-charged HRPs are therefore well immobilized onto the PLL surface at $\mathrm{pH} 6.5 \sim 8.5$, mainly through electrostatic interactions. No further modification of the slide or the HRP is needed. In this study, all the HRP printing 
solutions were prepared in $0.05 \mathrm{M} \mathrm{C}-\mathrm{P}$ buffer solutions with $\mathrm{pH}$ 7.4. Before the enzyme kinetics study, the blank surfaces in the chamber were passivated against nonspecific adsorption of proteins by $1 \times \mathrm{BSA}$ solution for $5 \mathrm{~min}$ at room temperature. The chamber was then washed three times by $1 \times$ wash solution containing $0.02 \%$ Tween 20 to wash away any non-adsorbed enzyme or BSA molecules. After that, the chamber was washed three more times by $0.05 \mathrm{M}$ pH 5.1 C-P buffer. In the mean time, one image of the buffer solution was taken as background as shown in Figure 3a. The enzyme array was then ready for applying substrate solution.

The CCD was started before the addition of substrate solution to ensure the catalytic reaction at the very beginning was recorded. Raw images for a selected HRP-catalyzed reaction on a microarray at $1.7,8.3$ and $15 \mathrm{~s}$ are shown in Figure $3 \mathrm{~b}$-d. After one experiment, the substrate solution was removed and the chamber was washed three times by $0.05 \mathrm{M} \mathrm{pH} 5.1 \mathrm{C}-\mathrm{P}$ buffer. The next substrate solution was then applied onto the microarray. The layout of this microarray is shown in Figure 3e. On the test microarray, two types of HRPs, type II and type VI-A, with printing concentrations from 7.0 to $3.0 \mu \mathrm{M}$, were imaged at the same time. Five replicates were spotted for each enzyme at each concentration. In Figure 3, the left five columns are HRP-II spots, while the right five columns are HRP-VIA spots. From top to bottom, the enzyme printing solution concentrations were $7.0,5.0,4.0,3.5,3.25$, and $3.0 \mu \mathrm{M}$ respectively. The initial TMB concentrations ranged from 0.05 to $2 \mathrm{mM}$ and the $\mathrm{H}_{2} \mathrm{O}_{2}$ concentration was held constant at $1.2 \mathrm{mM}$.

Enzyme kinetic curves. The raw intensity images were converted to product concentration images pixel-by-pixel using WinView software through Eq. 1. 


$$
\left[\mathrm{TMB}^{+\bullet}\right]=\mathrm{A} / \varepsilon b=-\log \left(1 / \mathrm{I}_{0}\right) / \varepsilon \mathrm{b}
$$

Here, $I$ is the intensity of a pixel on the raw image to be converted, $I_{0}$ is the intensity of the corresponding pixel on the background image which is taken with the C-P buffer right before each reaction, $\varepsilon$ is the absorption coefficient of $\mathrm{TMB}^{+\bullet}$ at $652 \mathrm{~nm}, \mathrm{~b}$ is the thickness of the reaction chamber. The corresponding concentration profiles for Figure $3 b-d$ are shown in Figure $3 \mathrm{f}-\mathrm{h}$, respectively. The uneven background image was thus normalized after the conversion. Enzyme reactivity screening could be easily achieved by simply comparing the product concentration (brightness) at each spot. For example, if every spot in one microarray contains a different enzyme at the same concentration, a brighter spot indicates a higher enzymatic activity of the enzyme on that spot.

Enzyme kinetics is evaluated using the Michaelis-Menten model (Eq. 2).

$$
V_{0}=V_{\max }[\mathrm{S}] /\left(K_{m}+[\mathrm{S}]\right)
$$

Here, $V_{0}$ is the initial rate of the enzyme reaction, $[\mathrm{S}]$ is the concentration of the substrate, $K_{m}$ is the Michaelis constant of the enzyme, $V_{m a x}$ is the maximum reaction rate, which is proportional to the enzyme concentration. $K_{m}$ is a constant independent of the enzyme concentration. The reaction rate of TMB could be calculated from the changes in the product concentration over time. In the CCD image, each enzyme spot has a diameter of about 17 pixels, corresponding to $165 \mu \mathrm{m}$ on the microarray. The center-to-center distance between neighboring spots is about 30 pixels which corresponds to $280 \mu \mathrm{m}$. In calculating the product concentration, the average of $30 \times 30$ pixels was used for each spot. By considering the 
thickness of the reaction chamber of $0.5 \mathrm{~mm}$, each HRP product spot occupies a solution volume of $0.28 \mathrm{~mm} \times 0.28 \mathrm{~mm} \times 0.5 \mathrm{~mm}=0.04 \mu \mathrm{l}$. In order to minimize the contributions from product diffusion, only the reaction data from the first $15 \mathrm{~s}$ were used. Figure 4 shows the reaction curves of selected HRP spots with the initial TMB concentration fixed at 1.0 $\mathrm{mM}$. The highest $\mathrm{TMB}^{+\bullet}$ concentration after $15 \mathrm{~s}$ is $4.3 \mu \mathrm{M}$, which corresponds to about $0.43 \%$ of the initial TMB concentration. For all other initial TMB concentrations, the converted substrates are $\leq 0.6 \%$ of the initial concentrations after $15 \mathrm{~s}$. Thus, for each enzyme spot, the initial rate $V_{0}$ can be determined as the slope of the product generation curve as function of time (Figure 4).

Data calibration. Although theoretically an enzyme array can be used many times without loss of activity, the immobilized enzyme suffers from activity loss under intensive washing, especially at lower $\mathrm{pH}$ when proteins are positively charged or are neutral. This is because enzyme molecules are immobilized on the PLL surface only through electrostatic interactions. At pH 7.4, the optimal pH for HRP molecules to adsorb onto the PLL surface, the activity loss under washing is still not negligible. Other factors such as denaturing may also be present. The loss of enzyme activity here is due to the decrease of the active enzyme molecule numbers on the surface. This loss is related to the contact time, i.e. reaction sequence number. Thus, all initial reaction rates in separate experiments can be calibrated according to a calibration curve obtained experimentally. The $1.0 \mathrm{mM}$ substrate solution was chosen as the standard to calibrate the reaction rates, as shown in Figure 5a. The standard solution was run as the first of every five experiments at various substrate concentrations on the same enzyme array. Each experiment was conducted for the same amount of time and the 
interval between every two experiments was fixed. Therefore, the experimental sequence number is directly proportional to the contact time of the microarray to the buffer and the substrate solutions. For each enzyme spot, a calibration curve is generated from the plot of the initial rates on that spot in the standard solution as a function of experimental sequence number (Figure 5a). Calibrated reaction rates are obtained through Eq. 3, where $x$ is the experimental sequence number. $V_{0}(1)$, which is a standard, is the un-calibrated reaction rate of the first of the series of 5 experiments. $V_{0}(x)$ is the un-calibrated reaction rate of the $x$ th experiment. $y(x)$ is the experimental value on the calibration curve for a given sequence number $x . V_{0}(1) / y(x)$ is the calibration factor for the $x$ th experiment. The calibrated reaction rate,

$$
V_{0}^{\prime}(x)=\left(V_{0}(1) / y(x)\right) * V_{0}(\mathrm{x})
$$

Figure 5a shows the initial rates in the standard substrate solution before and after calibration for one enzyme spot. After calibration, the other two standard initial rates, $V_{0}^{\prime}(6)$ and $V_{0}^{\prime}(11)$, were all calibrated to the same level of that in the first experiment, $V_{0}^{\prime}(1)$. Initial rates in the other experiments with various TMB concentrations were also calibrated according to their experimental sequence number (time). Figure $5 b$ shows the initial rates of a series of reactions with different substrate concentrations measured at one enzyme spot before and after calibration.

Kinetic data. Selected calibrated initial rates of immobilized HRP-II and HRP-VIA at different concentrations were plotted against substrate (TMB) concentration in Figure 6 (dots). For each enzyme spot on the slide, a $V_{\max }$ value and a $K_{m}$ value can be deduced from 
the Michaelis-Menten model by nonlinear regression (least-squares minimization) of the experimental data (curves in Figure 6) using Microsoft Excel software. The results of $V_{\max }$ and $K_{m}$ are shown in Table 1 and Table 2, respectively, according to the layout of the microarray. The first five columns (1-5) are the spots of HRP-II, while the last five columns (6-10) are the spots of HRP-VIA. The spots on each row (line) have the same printed enzyme concentration. The $V_{\max }$ value decreases as the HRP concentration decreases, while the $K_{m}$ value is independent to the enzyme concentration. The $K_{m}$ values for HRP-II and HRP-VIA obtained are $0.45 \mathrm{mM}$ (with standard deviation of $0.06 \mathrm{mM}$ ) and $0.47 \mathrm{mM}$ (with standard deviation of $0.03 \mathrm{mM}$ ), respectively, based on the results in Table 2 .

Since $K_{m}$ is a constant independent of the enzyme concentration, using one $K_{m}$ variant for all different HRP concentrations in the regression should give more reliable results. By setting $K_{m}$ as a true constant, nonlinear regression of the Michaelis-Menten model give $K_{m}$ values of $0.471 \mathrm{mM}$ for HRP-II and $0.474 \mathrm{mM}$ for HRP-VIA. This indicates that there is no difference between these two types of HRPs. The $K_{m}$ values are in the same range as the literature value of $0.247 \mathrm{mM}^{12}$ determined in homogenous solution. The variance can be attributed to the influence of immobilization and from surface effects.

With calibration, one enzyme microarray can be used multiple times. We found that reasonable calibration factors can be obtained for up to 20 consecutive experiments. This is more than enough to generate a complete kinetic curve (Figure 6) for every enzyme spot on the slide. In comparison with existing methods that require multiple enzyme subarrays for each kinetics curve, our method not only reduces the cost, but also greatly reduces the 
uncertainties caused by the immobilization and printing processes. Our current setup can monitor up to $17 \times 17$ enzyme spots at a time, which means that kinetic constants of up to 289 different enzymes can be obtained simultaneously from one set of experiments carried out on the same enzyme microarray. The detection throughput can be further increased by using a larger CCD chip, lowering the magnification of the image, and/or decreasing the spot size. Lowering magnification can be easily achieved by changing objective lens, but precision may suffer due to the reduction in the number of pixels utilized for each measurement. Decreasing the spot size means consuming even less enzyme per assay. The immobilization method used in this study is straightforward, with the involvement of only electrostatic interactions. Thus, this method can be easily adopted to study other enzymes. Finally, the absorption detection method is universally applicable since most organic molecules absorb light and no modifications of the substrate are needed.

\section{Conclusions}

We have developed an efficient, novel in-situ high-throughput enzyme kinetics method on an enzyme microarray. The enzyme microarrays were generated on PLL coated glass slides by a micro-spotting robotic system. The kinetics analysis relies on the Michaelis-Menten model. Reactions at hundreds of enzyme spots could now be efficiently monitored at the same time. The same enzyme array can be used for multiple times based on calibration with a standard substrate solution. The Michaelis constant $K_{m}$ obtained using this method is comparable to the one gotten from the homogenous solution. The method reported here is likely to be of value for clinical diagnostics, drug screening, and new catalyst discovery. 


\section{Acknowledgments}

We thank the MicroArray Facility at the Center for Plant Genomics, Iowa State University for help in printing the microarrays. E.S.Y. thanks the Robert Allen Wright Endowment for Excellence for support. The Ames Laboratory is operated for the U.S. Department of Energy by Iowa State University under Contract W-7405-Eng-82. This work was supported by the Director of Science, Office of Basic Energy Sciences, Division of Chemical Sciences.

\section{References}

1. Mao, H. B.; Yang, T. L.; Cremer, P. S. Anal. Chem. 2002, 74, 379-385.

2. Seong, G. H.; Heo, J.; Crooks, R. M. Anal. Chem. 2003, 75, 3161-3167.

3. MacBeath, G.; Schreiber, S. L. Science 2000, 289, 1760-1763.

4. Zhu, H.; Bilgin, M.; Bangham, R.; Hall, D.; Casamayor, A.; Bertone, P.; Lan, N.; Jansen, R.; Bidlingmaier, S.; Houfek, T.; Mitchell, T.; Miller, P.; Dean, R. A.; Gerstein, M.; Snyder, M. Science 2001, 293, 2101-2105.

5. Houseman, B. T.; Huh, J. H.; Kron, S. J.; Mrksich, M. Nature Biotechnol. 2002, 20, 270274.

6. Eppinger, J.; Funeriu, D. P.; Miyake, M.; Denizot, L.; Miyake, J. Angew. Chem., Int. Ed. 2004, 43, 3806-3810.

7. Funeriu, D. P.; Eppinger, J.; Denizot, L.; Miyake, M.; Miyake, J. Nature Biotechnol. 2005, 23, 622-627.

8. Elving, P. J.; Markowitz, J. M.; Rosenthal, I. Anal.Chem. 1956, 28, 1179-1180.

9. Schonbaum, G. R.; Lo, S. J. Biol. Chem. 1972, 247, 3353.

10. Frey, A.; Meckelein, B.; Externest, D.; Schmidt, M. A. J. Immunol. Methods 2000, 233, 
47-56.

11. Josephy, P. D.; Eling, T.; Mason, R. P. J. Biol. Chem. 1982, 257, 3669-3675.

12. Sentchouk, V. V.; Grintsevich, E. E. Biochem.-Moscow 2004, 69, 201-207. 
$n$

\begin{tabular}{|c|c|c|c|c|c|c|c|}
\hline & $\begin{array}{l}\text { 옴 } \\
\text { 莒 } \\
\text { 号 }\end{array}$ & 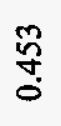 & 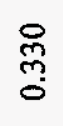 & $\begin{array}{l}\text { gి } \\
\text { ஸे }\end{array}$ & ஸั & 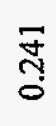 & ָู \\
\hline & $\begin{array}{l}\text { a } \\
\text { ثे } \\
\text { 号 }\end{array}$ & 禀 & ָָ & $\stackrel{m}{\dddot{m}}$ & 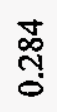 & 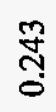 & $\underset{\widetilde{N}}{\tilde{0}}$ \\
\hline & $\begin{array}{l}\infty \\
\text { i் } \\
\text { 足 }\end{array}$ & $\begin{array}{l}\text { 尺 } \\
\text { ñ. } \\
0\end{array}$ & 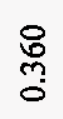 & in & 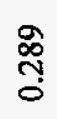 & तु & $\begin{array}{l}\text { ్ㅜ } \\
\text { ర }\end{array}$ \\
\hline & $\begin{array}{l}\text { 2. } \\
\text { 옹 }\end{array}$ & ষ্ণ & 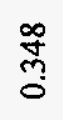 & 웜 & 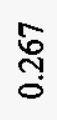 & 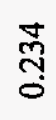 & $\underset{\alpha}{\sigma}$ \\
\hline & 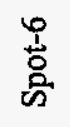 & \&̊ & 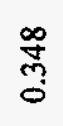 & 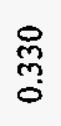 & $\stackrel{\infty}{\stackrel{\text { స్ }}{0}}$ & ָิ & $\frac{F}{0}$ \\
\hline & $\begin{array}{l}\text { 营 } \\
\text { की }\end{array}$ & 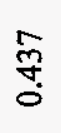 & $\underset{m}{\infty}$ & $\underset{\hat{~}}{0}$ & 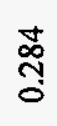 & $\frac{\infty}{0}$ & $\frac{\overrightarrow{0}}{0}$ \\
\hline & $\begin{array}{l}\frac{7}{1} \\
0 \\
0\end{array}$ & ণ্ণ & 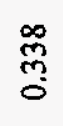 & $\underset{ }{\stackrel{\Sigma}{~}}$ & $\begin{array}{l}\text { ᄋ } \\
\text { ஸ్ } \\
0\end{array}$ & $\underset{⿱ 亠 乂}{\Delta}$ & $\underset{n}{\stackrel{n}{0}}$ \\
\hline & $\begin{array}{l}m \\
\stackrel{n}{0} \\
\frac{0}{2}\end{array}$ & 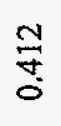 & 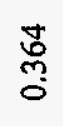 & 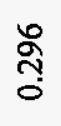 & $\stackrel{\infty}{\text { స్ }}$ & 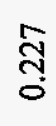 & $\frac{9}{0}$ \\
\hline & $\begin{array}{l}\text { I } \\
\text { 莒 } \\
\text { क }\end{array}$ & $\underset{\dot{\sigma}}{\stackrel{\sigma}{0}}$ & 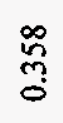 & $\underset{\text { ஸे }}{\vec{\infty}}$ & 命 & $\stackrel{\circ}{\stackrel{ }{0}}$ & ণ্ণ్ \\
\hline & $\begin{array}{l}\vec{\vdots} \\
\text { 莒 } \\
\text { क }\end{array}$ & $\begin{array}{l}\overline{0} \\
0 \\
0\end{array}$ & $\underset{\tilde{m}}{\sigma}$ & $\begin{array}{l}\text { đั } \\
\text { O }\end{array}$ & $\begin{array}{l}\infty \\
\stackrel{\infty}{1} \\
0 \\
0\end{array}$ & ్ㅗㅇ & $\frac{8}{0}$ \\
\hline & & 岕 & 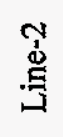 & $\stackrel{?}{\stackrel{9}{\leftrightarrows}}$ & 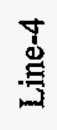 & \& & 号 \\
\hline 嵒 & 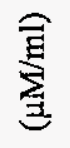 & $\stackrel{\circ}{\circ}$ & $\stackrel{\circ}{i}$ & $\stackrel{\circ}{\forall}$ & $\dddot{m}$ & ָุ & $\underset{\text { ri }}{\circ}$ \\
\hline
\end{tabular}




\begin{tabular}{|c|c|c|c|c|c|c|}
\hline 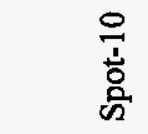 & $\begin{array}{l}\overrightarrow{0} \\
\vdots \\
0\end{array}$ & 导 & 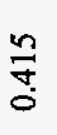 & 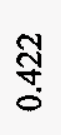 & $\stackrel{0}{0}$ & $\begin{array}{l}\text { त్ } \\
\text { on }\end{array}$ \\
\hline $\begin{array}{l}\text { iे } \\
\text { 总 } \\
\text { 员 }\end{array}$ & $\frac{a}{n}$ & 各 & $\begin{array}{l}\text { के } \\
\text { fे }\end{array}$ & 莳 & $\stackrel{\text { }}{\sigma}$ & $\begin{array}{l}\infty \\
\stackrel{?}{0} \\
0\end{array}$ \\
\hline $\begin{array}{l}\infty \\
\text { 10 } \\
\text { in }\end{array}$ & $\begin{array}{l}\text { ồ } \\
\text { on }\end{array}$ & 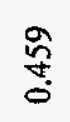 & 热 & 竎 & $\stackrel{\infty}{\stackrel{\infty}{\leftarrow}}$ & $\frac{5}{8}$ \\
\hline 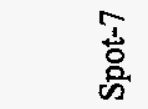 & 哭 & 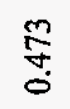 & 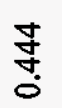 & $\underset{0}{\vec{f}}$ & 莣 & 尽 \\
\hline $\begin{array}{l}\text { : } \\
\text { ò } \\
\text { o. }\end{array}$ & $\begin{array}{l}\overrightarrow{\widehat{N}} \\
0\end{array}$ & $\begin{array}{l}\infty \\
\stackrel{\infty}{+} \\
0\end{array}$ & $\frac{8}{8}$ & $\begin{array}{l}\text { to } \\
\text { J }\end{array}$ & 苗 & 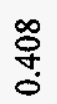 \\
\hline $\begin{array}{l}\text { n } \\
\text { 莒 } \\
\text { क }\end{array}$ & $\begin{array}{l} \pm \\
\vdots \\
\vdots \\
0\end{array}$ & $\begin{array}{l}\text { पे } \\
\text { nू }\end{array}$ & $\stackrel{n}{\stackrel{n}{0}}$ & 苑 & 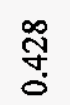 & 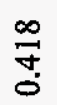 \\
\hline $\begin{array}{l}\frac{1}{\Delta} \\
0 \\
0\end{array}$ & त్ & $\begin{array}{l}\text { 尺े } \\
\text { है }\end{array}$ & స్ & 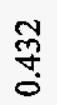 & $\underset{0}{\stackrel{J}{*}}$ & ్ֶֻలై \\
\hline 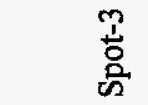 & $\begin{array}{l}0 \\
\text { hn } \\
0\end{array}$ & 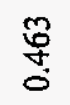 & $\begin{array}{l}\vec{\sigma} \\
0 \\
0\end{array}$ & 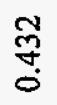 & 옴 & 草 \\
\hline 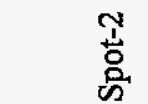 & 岕 & 只 & $\underset{8}{\text { f }}$ & $\begin{array}{l}\overline{5} \\
\text { fo }\end{array}$ & $\stackrel{0}{\stackrel{7}{0}}$ & $\begin{array}{l}\vec{\infty} \\
\text { on } \\
0\end{array}$ \\
\hline $\begin{array}{l}\overrightarrow{\mathbf{D}} \\
\text { 吕 }\end{array}$ & 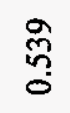 & ্ָ & $\begin{array}{c}\tilde{N} \\
\stackrel{m}{0}\end{array}$ & 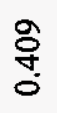 & \begin{tabular}{l}
$\tilde{o}$ \\
\multirow{0}{0}{}
\end{tabular} & $\begin{array}{c}\infty \\
\text { in } \\
0\end{array}$ \\
\hline & 总 & 岁 & 离 & 苋 & $\begin{array}{l}\text { 崩 } \\
\text { 忽 }\end{array}$ & 总 \\
\hline 凯 㤩 & $\stackrel{\circ}{i}$ & $\stackrel{\circ}{i}$ & $\stackrel{\circ}{+}$ & m & $\underset{n}{~}$ & $\stackrel{\ddot{m}}{\dot{m}}$ \\
\hline
\end{tabular}




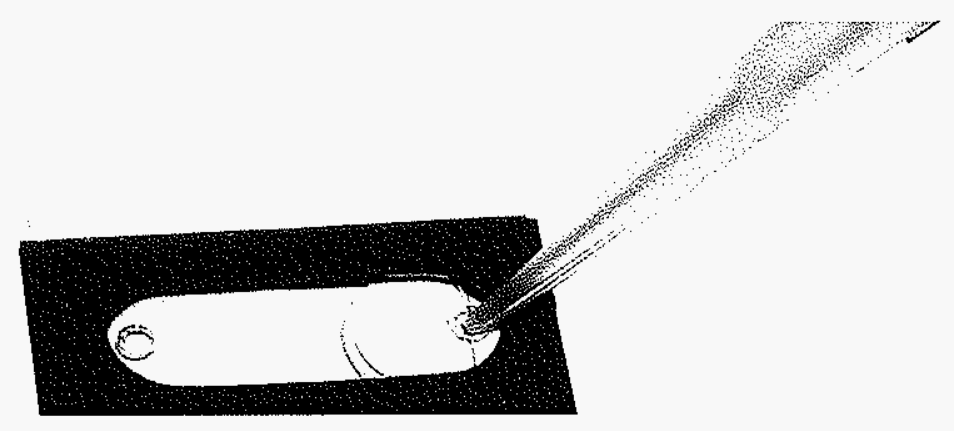

(a)

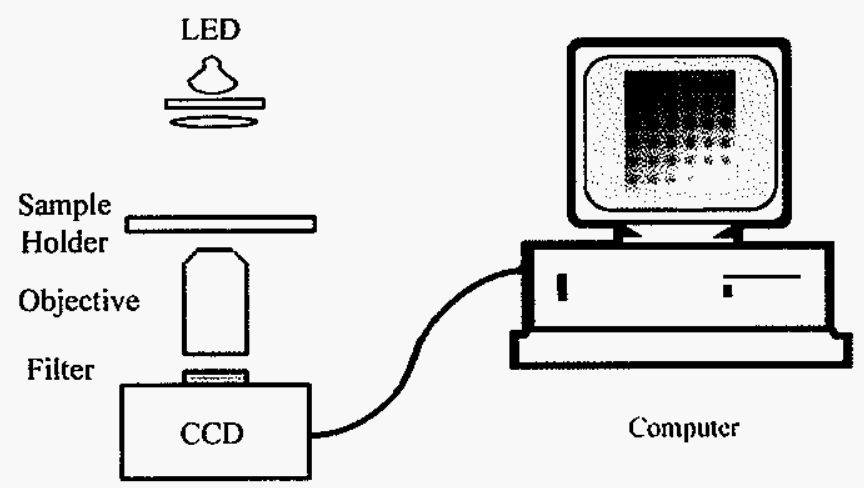

(b)

Figure 1. (a) Reaction chamber with a micropipette tip on the right. (b) Schematic illustration of the experimental setup. 

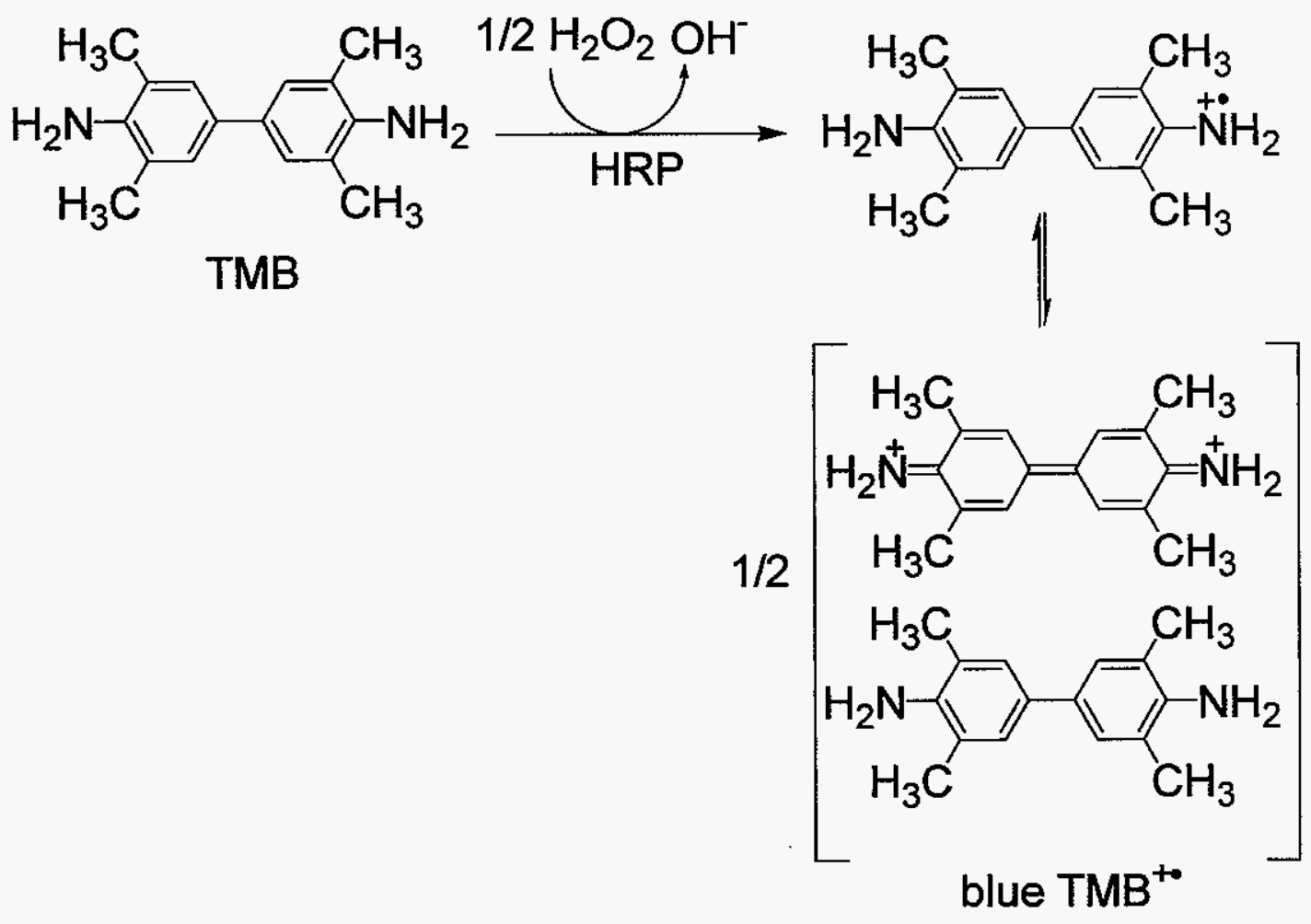

Figure 2. Reaction scheme for the horseradish peroxidase catalyzed oxidation of TMB by $\mathrm{H}_{2} \mathrm{O}_{2}$ 


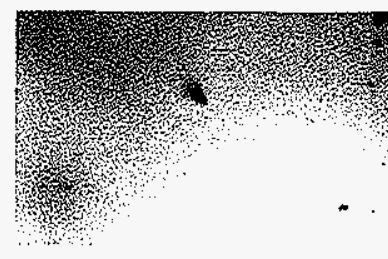

(a)

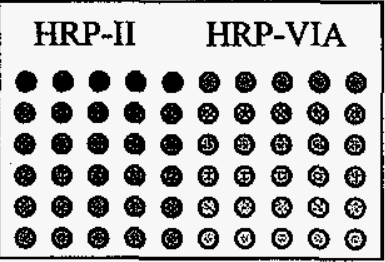

(e)
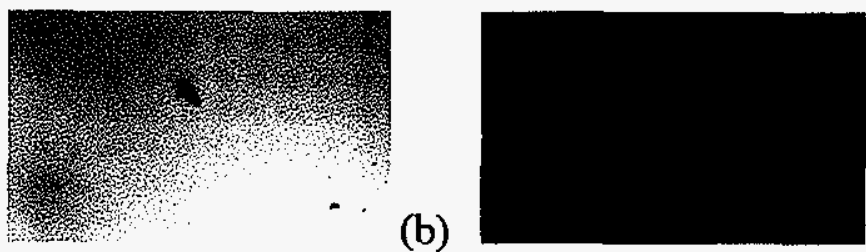

(f)
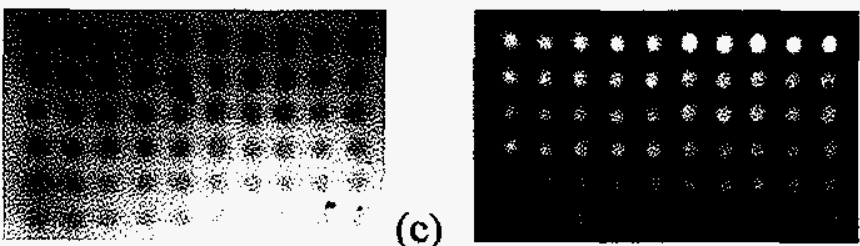

(g)
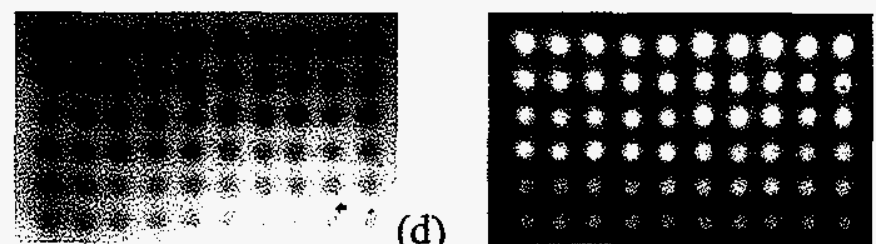

(d)

(h)

Figure 3. The conversion of raw intensity data to product concentration data with WinView software. (a) Background image. (b)-(d) Raw images of one microarray after incubation of the enzyme catalyzed reaction for $1.7,8.3$, and $15 \mathrm{~s}$, respectively. (e) Illustration of the enzyme microarray arrangement. Series of solutions of two types of HRPs at different concentrations were printed on this array. Each sample has five replicates in a row. HRP concentrations from top to bottom are 7.0, 5.0, 4.0, 3.5, 3.25, 3.0 $\mu \mathrm{M}$ respectively. (f)-(h) Product concentration profiles obtained by converting the raw image data in (b)-(d) via Eq. 1, respectively. 


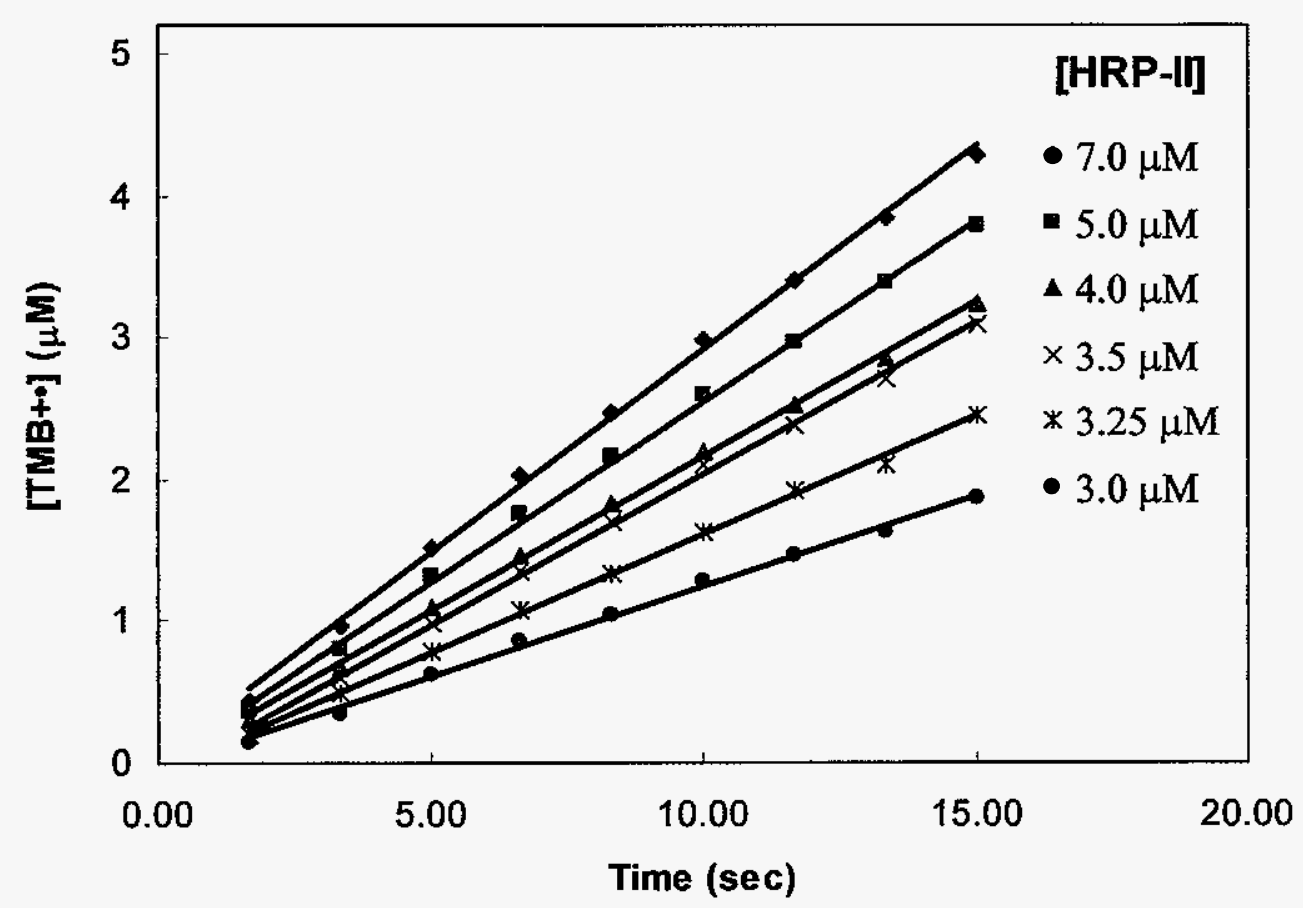

Figure 4. Plot of product concentrations [TMB $\left.{ }^{+\bullet}\right]$ vs. time on selected HRP-II spots at $[\mathrm{TMB}]_{0}=1.0 \mathrm{mM}$. The concentrations of the HRP printing solutions range from 3.0 to 7.0 $\mu \mathrm{M}$, respectively. 

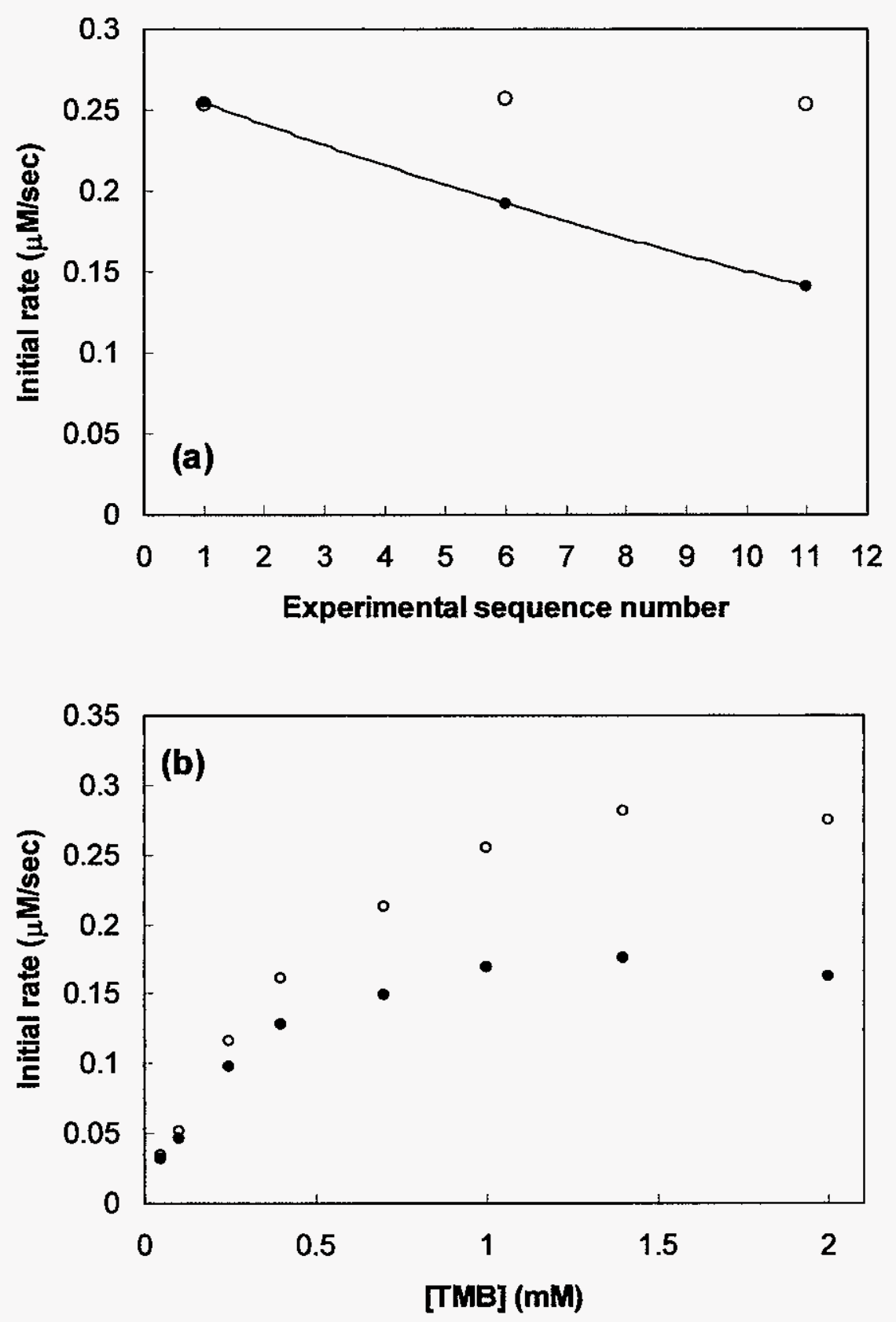

Figure 5. (a) A selected calibration curve with data points before $(\bullet)$ and after $(0)$ normalization. (b) A series of initial reaction rates at one selected enzyme spot before (•) and after (O) normalization. 

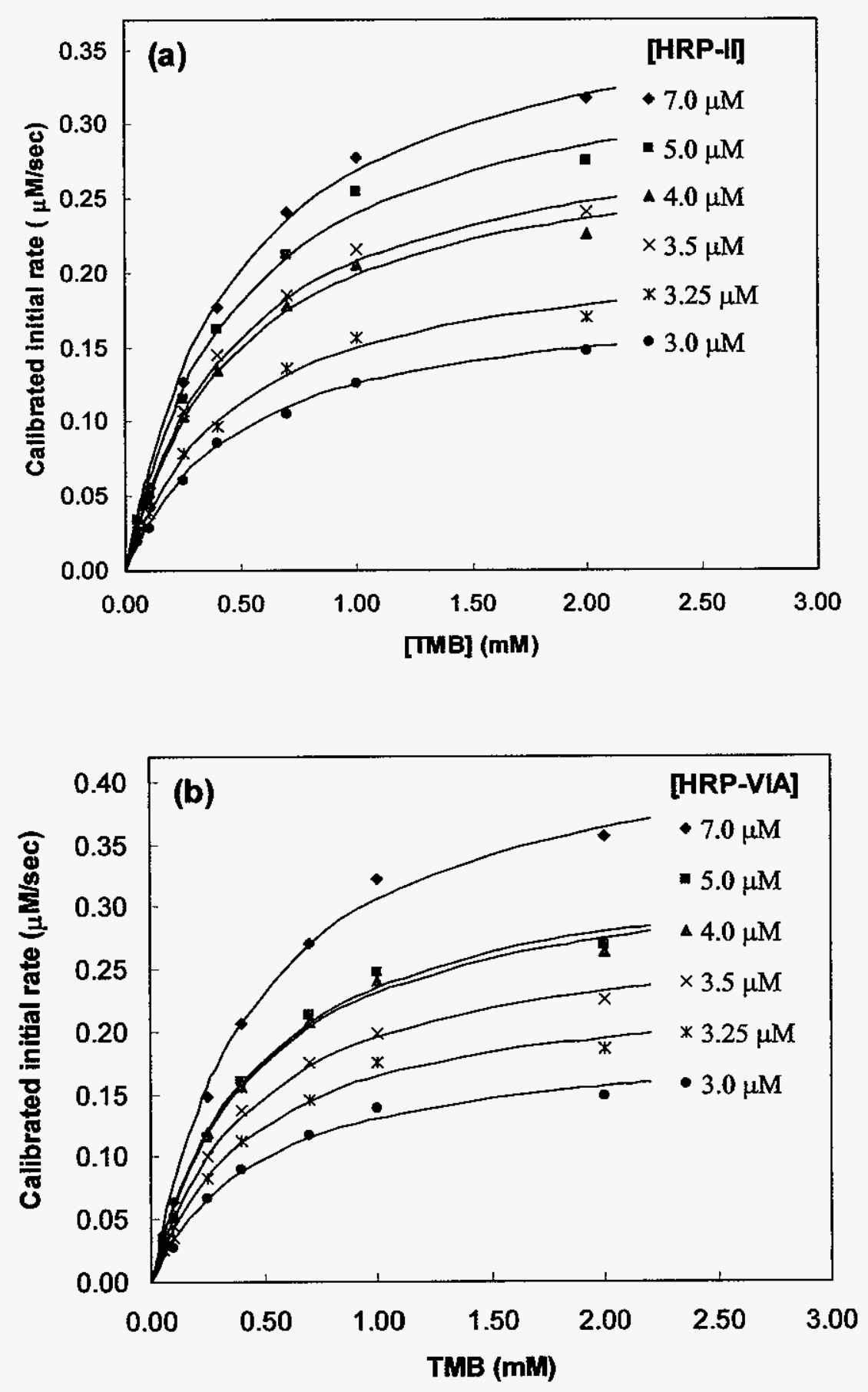

Figure 6. Plot of normalized initial reaction rates of HRP-II (a) and HRP-VIA (b) at various printed enzyme concentrations $(3.0 \sim 7.0 \mu \mathrm{M})$ vs. TMB concentration, and the corresponding best-fit curves to the Michaelis equation. 


\section{CHAPTER 4. FLUORESENCE DETECTION OF ADENOSINE 5'-DIPHOSPHATE}

\section{Introduction}

Protein kinase. Protein kinases are enzymes that catalyze the phosphorylation of other proteins/peptides by Adenosine 5'-triphosphate (ATP). The reaction forms phosphorylated protein/peptide and Adenosine 5'-diphosphate (ADP). Analysis of human genome yielded 518 protein kinases. Among these kinases, about 90 of them catalyze the phosphorylation of tyrosine residues, whereas the rest of them catalyze phosphorylation of serine and threonine residues. ${ }^{1}$ The phosphorylation events help to regulate cell-signaling network. Malfunctions of cellular signaling may cause diseases such as cancers and diabetes. ${ }^{2}$ Thus, protein kinases have become a very important class of drug targets over the past 20 years.

Kinase activity detection. There are many different approaches for the detection of kinase activities. ${ }^{3}$ Homogeneous assays include fluorescence polarization (FP), ${ }^{4}$ time-resolved fluorescence energy transfer (TR-FRET) ${ }^{5}$ luciferase detection of residual ATP, ${ }^{6}$ multiplexed capillary electrophoresis (CE), ${ }^{7}$ and coupled-enzyme detection of accumulated ADP. ${ }^{8}$

Heterogeneous assays include ${ }^{32} \mathrm{P}-\mathrm{ATP}$ based detection ${ }^{9}$ and enzyme-linked immunosorbent assay (ELISA) based detection. ${ }^{10}$

FP assay uses fluorophore-labeled tracer peptide to compete with the phosphorylated peptide produced from kinase reaction for binding to a phosphopeptide-specific antibody.

Fuorescence from antibody-bound tracer is more polarized than the free tracer. The more the phosphorylated peptide product present, the lower the polarization of the emission light. This 
method is very effective, but is limited by the availabilities of the phosphopeptide-specific antibodies.

In TR-FRET assays, the substrate peptide is first labeled with fluorophore. Then, after phosphorylation, europium-labeled phosphopeptide-specific antibody is used to bind with the phosphorylated peptide product and bring the europium close to the fluorophore, resulting in the emission of light.

Luciferase detection of ATP detects the amount of ATP left in the system. This assay uses luciferin/luciferase enzyme system to quantify the decrease of ATP concentration resulting from kinase reaction. The assay generates chemiluminescence signal, which is proportional to the ATP concentration.

Mutiplexed $\mathrm{CE}$ detection of kinase activity utilizes the separation ability of $\mathrm{CE}$ to separate the peptide substrate from the phosphorylated peptide product. A universal detection method, $214 \mathrm{~nm} \mathrm{UV}$ absorption detection, is used for detecting the substrate and the phosphorylated product. Quantification is achieved through comparing the peak areas of the two peaks.

One example of coupled-enzyme detection of accumulated ADP assay uses pyruvate kinase and pyruvate oxidase to convert the ADP generated from kinase reaction to hydrogen peroxide $\left(\mathrm{H}_{2} \mathrm{O}_{2}\right) . \mathrm{H}_{2} \mathrm{O}_{2}$ is then detected using a fluorescence substrate and horseradish peroxidase (HRP).

${ }^{32} \mathrm{P}$-ATP based detection generally involves the immobilization of peptide substrate. The radioactive phosphate group is transferred from ATP molecule to immobilized peptide. Activities of kinasea are obtained by phosphorimager analysis after incubation. 
ELISA based assays also use immobilized peptide substrate. In this case, the immobilized phosphorylated peptide product is conjugated with fluorophore-labeled phosphopeptidespecific antibody after the kinase reaction. Quantification is achieved by reading the fluorescent count.

Each of the above methods has its own advantages and disadvantages. For example, ${ }^{32} \mathrm{P}$-ATP based method is very accurate and sensitive, but requires handling the radioisotope. Other methods except multiplexed CE either require specific antibodies or require multiple extra enzymes to perform the kinase activity detection.

In our study, we tried to find a quick, universal, low cost detection method for kinases. ADP is a universal product of kinase reactions. Direct detection of ADP under the existence of ATP is highly desirable. Herein we report the fluorescence emission spectrum of ADP and the fluorescence detection of ADP using three different detection systems.

\section{Experimental Section}

Reagents. ADP sodium salt (Cat. \#A2754), ATP disodium salt (Cat. \#A7699), HEPES, HEPES sodium salt, and Ethylenediaminetetraacetic (EDTA) acid disodium salt dihydrate were obtained Sigma-Aldrich (St. Louis, MO). Milli-Q (Millipore, Billerica, MA, USA) water was used to prepare all the solutions. $2 \mathrm{M}$ sodium hydroxide $(\mathrm{NaOH})$ was used to adjust $\mathrm{pH}$ for all solutions as needed.

The following stock solutions were prepared in water from their solid forms: $100 \mathrm{mM}$ ADP solution in water, $\mathrm{pH} 4.0 ; 100 \mathrm{mM}$ ATP solution in water, $\mathrm{pH} 3.2 ; 100 \mathrm{mM}$ HEPES buffer, pH 8.0; 100mM EDTA solution, $\mathrm{pH} 8.0$. 
Fluorescence detection. The fluorescence spectra of ADP, ATP, and relative buffer solutions were detected by a fluorescence spectrometer (Model LS-50B; PerkinElmer Life And Analytical Sciences, Inc., Waltham, MA). Laser-induced fluorescence (LIF) detection of ADP was carried out using both intensified charge-coupled device (ICCD) camera system and capillary electrophoresis (CE) system. Details are described below.

All fluorescence spectra were measured using a 4-ml quartz cuvette with 1-mm path length at excitation wavelength of $405 \mathrm{~nm}$.

The LIF detection system using ICCD is similar to those used in previous studies done in our group. ${ }^{11}$ Briefly, the laser beam from a 405 nm diode-laser (Model\# BWB-405-40-E; B\&W Tek Inc., Newark, DE) was focused at the center of a square capillary ( $75-\mu \mathrm{m}$ i.d., $365-\mu \mathrm{m}$ o.d.; Polymicro Technologies, Phoenix, AZ, USA). Fluorescence from ADP solutions was collected by an ICCD with a microscope objective at the right angle of the incident laser beam. A $520 \mathrm{~nm}$ bandpass filter (Bandwidth $35 \mathrm{~nm}$; Semrock, Rochester, NY) is placed between the objective and the ICCD. The ICCD collected images with $300 \mathrm{~ms}$ exposure time at $2 \mathrm{~Hz}$.

The CE setup is similar to those used in previous studies. ${ }^{12} 405 \mathrm{~nm}$ laser beam was focused at the center of a capillary (150- $\mu \mathrm{m}$ i.d., $365-\mu \mathrm{m}$ o.d.; Polymicro Technologies, Phoenix, AZ, USA) through a cylindrical lens. Fluorescence from ADP solutions was collected by a photomultiplier tube (PMT) with a microscope objective at the right angle of the incident laser beam. A $520 \mathrm{~nm}$ bandpass filter (Bandwidth $35 \mathrm{~nm}$; Semrock, Rochester, NY) is placed in between the objective and the PMT. First, signal of ADP at a certain concentration is obtained by filling the whole capillary with the ADP sample. Then, background signal is 
obtained by injecting buffer solution into the capillary through gravity flow. Net fluorescence signal of the ADP sample is then obtained by subtracting the background signal from the ADP sample signal.

\section{Results and Discussion}

Fluorescence spectra of ADP and ATP. The chemical structures of ADP and ATP are shown in Figure 1. In our study, we found that as $\mathrm{pH}$ changes, the fluorescence emission intensity of ADP solutions changed a lot. Figure 2 shows emission spectra of ADP solutions at different $\mathrm{pH}$ with excitation wavelength of $405 \mathrm{~nm}$. All solutions contain $10 \mathrm{mM}$ ADP, 10 mM HEPES, and $50 \mathrm{mM}$ EDTA. At higher $\mathrm{pH}$, the ADP solution has a broad emission peak with emission maximum at about $500 \mathrm{~nm}$. From $\mathrm{pH} 5.0$ to $\mathrm{pH} 8.3$, the intensity of this emission peak increases with $\mathrm{pH}$. The small emission peak at around $470 \mathrm{~nm}$ is the Raman emission peak of water, which can be subtracted as background. More detail relationship of the net emission intensities of ADP vs. $\mathrm{pH}$ is shown in Figure 3. The emission intensity of $\mathrm{ADP}$ at $500 \mathrm{~nm}$ increases as the $\mathrm{pH}$ increases while the $\mathrm{pH}$ is low. When $\mathrm{pH}$ reaches 7.8 , the emission intensity of ADP reaches maximum and remains stable at higher pHs.

On the other hand, the emission spectra of ATP did not have significant change while the pH changes (Figure 4). The emission intensity at $500 \mathrm{~nm}$ for ATP solutions is slightly higher when $\mathrm{pH}$ is higher than 8 . Comparison of net emission spectra of ADP and ATP at $\mathrm{pH} 8$ (Figure 5) indicates the huge difference of these two species. This fluorescence difference has the potential of being used in the direct analysis of activities of enzymes that generate ADP from ATP, for example, kinases and ATPases. 
The reason for the fluorescence emission difference between ADP and ATP is not clear. Some researchers reported that the fluorescence increase of ADP was because of the existence of EDTA. ${ }^{13}$ However, our study indicates that ADP solutions at $\mathrm{pH} 8.0$ have identical net emission spectra with or without EDTA (Figure 6). Also, similar emission patterns and intensities for ADPs were observed in $\mathrm{pH} 7.5$ Tris- $\mathrm{HCl}$ buffer, in $\mathrm{pH} 7.5$ gly-gly buffer, and in pure water after the $\mathrm{pH}$ was adjusted to about 8.0 by $2 \mathrm{M} \mathrm{NaOH}$.

Solution pHs. From previous results, we learned that when $\mathrm{pH}$ values are lower than 7.8 , the emission efficiency of ADP decreases as sample $\mathrm{pH}$ decreases. Thus, it is very important to keep the sample $\mathrm{pHs}$ in the range of $7.8-8.0$, the optimum $\mathrm{pH}$ value for both the ADP detection and the kinase reaction. Both $\mathrm{ADP} \bullet \mathrm{Na}$ and $\mathrm{ATP} \bullet 2 \mathrm{Na}$ are weak acids. The $\mathrm{pH}$ values of $100 \mathrm{mM} \mathrm{ADP} \bullet \mathrm{Na}$ and $\mathrm{ATP} \bullet 2 \mathrm{Na}$ water solutions are 4.0 and 3.2 respectively. When ADP or ATP concentrations are high, $2 \mathrm{M} \mathrm{NaOH}$ was used to adjust the sample pHs in order to keep the $\mathrm{pH}$ values at $7.8-8.0$.

Most kinase assays contain EDTA. The water solution of EDTA $\bullet 2 \mathrm{Na}$ is also acidic. Its $\mathrm{pH}$ should be adjusted to 8.0 by $\mathrm{NaOH}$ before use.

Detection limit of ADP. Theoretically, the lowest amount of ADP able to be detected by fluorescence spectrometer was $22 \mu \mathrm{M}$ (Figure 7; Net RFU calculated from the standard curve was $0.03,3$ times of the standard deviation of background solution) in the existence of $1 \mathrm{mM}$ ATP, the normal ATP concentration used in kinase reactions. The linear detection range of ADP using fluorescence spectrometer is $22 \mu \mathrm{M}$ to above $3 \mathrm{mM}\left(\mathrm{r}^{2}=0.998\right)$. 
An ADP standard curve using the ICCD detection system is shown in Figure 8. Linear detection range of $15 \mu \mathrm{M}$ to above $100 \mu \mathrm{M}$ is obtained $\left(\mathrm{r}^{2}=0.987\right)$. Standard deviations and average counts $(n=40)$ for all data points are listed in Table 1. From the standard curve, the lowest amount of ADP able to be detected by ICCD is $15 \mu \mathrm{M}$, which equals to 84 counts, 3 times of the standard deviation.

The standard curved of ADP using CE detection system is shown in Figure 9. The calculated detection limit of ADP is about $3.6 \mu \mathrm{M}$, which equals to 0.75 PMT counts, 3 times of the background standard deviation.

\section{Conclusions}

We carefully studied the fluorescence spectra of ADP and ATP at different pHs. The emission spectrum of ADP shows a broad emission peak at $460-530 \mathrm{~nm}$ when excited with $405 \mathrm{~nm}$ light. When using shorter or longer excitation wavelength, similar spectra were obtained for ADP solutions but with lower emission intensity. Spectra of ATP show much lower fluorescence intensity within the same range. The detection limits obtained for ADP under the existence of $1 \mathrm{mM}$ ATP are 22, 15, and 3.6 $\mu \mathrm{M}$ for using fluorometer, laser-ICCD, and laser-PMT respectively. The fluorescence efficiency of ADP is not affected by the addition of other components, such as HEPES, EDTA, etc. Potentially, fluorescence detection of ADP could be used as a direct detection method for kinase activities. 


\section{Acknowledgments}

We thank Ji-young Lee and Aoshuang Xu for their help in building the ICCD and CE detection systems. E.S.Y. thanks the Robert Allen Wright Endowment for Excellence for support. The Ames Laboratory is operated for the US Department of Energy by Iowa State

University under Contract No. W-7405-Eng-82. This work was supported by the Director of Science, Office of Basic Energy Sciences, Division of Chemical Sciences and by the National Institutes of Health.

\section{References}

1. Manning, G.; Whyte, D. B.; Martinez, R.; Hunter, T.; Sudarsanam, S. Science 2002, 298, 1912-1934.

2. Cohen, P.; Nat. Rev. Drug Discovery 2002, 1, 309-315.

3. von Ahsen, O.; Bomer, U. Methods Mol. Biol. 2002, 190, 481-490.

4. Fowler, A.; Swift, D.; Longman, E.; Acornley, A.; Hemsley, P.; Murray, D.; Unitt, J.;

Dale, I.; Sullivan, E.; Coldwell, L. Anal. Biochem. 2002, 308, 223-231.

5. Park, U. W.; Cummings, R. T.; Wu, L.; Zheng, S.; Cameron, P. M.; Woods, A.; Zaller, D. M.; Mercy, A. I.; Hermes, J. D. Anal. Biochem. 1999, 269, 94-104.

6. Koresawa, M.; Okabe, T. Assay Drug Dev. Technol. 2004, 2, 153-160.

7. He, Y; Yeung, E. S. Electophoresis 2003, 24, 101-108.

8. Charter, N. W.; Kauffman, L.; Singh, R.; Eglen, R. M. J. Biomol. Screening 2006, 11, 390-399.

9. Houseman, B. T.; Huh, J. H.; Kron, S. J.; Mrksich, M. Nature Biotechnol. 2002, 20, 270274. 
10. Horiuchi, K. Y.; Wang, Y.; Diamond, S. L.; Ma, H. J. Biomol. Screening 2006, 11, 48-56.

11. Lee, J. Y.; Li, H. W.; Yeung, E. S. J. Chromtogr. A 2004, 1053, 174-179.

12. Yeung, E. S.; Wang, P.; Li, W.; Giese, R. W. J. Chromtogr. 1992, 608, 73-77.

13. Castillo, G.; Mitchell, R. L.; Mulligan, J. A. PCT Int. Appl. WO 2005069725, 2005, 20 pp. 
Table 1. Average and standard deviation of ADP fluorescence signals obtained by ICCD. $[\mathrm{ATP}]=1 \mathrm{mM} ;[\mathrm{HEPES}]=10 \mathrm{mM} ; \mathrm{pH}=8.0$.

\begin{tabular}{|c|c|c|}
\hline $\begin{array}{c}\text { ADP } \\
\text { Concentration } \\
(\mu \mathrm{M})\end{array}$ & $\begin{array}{c}\text { Average ICCD } \\
\text { count }\end{array}$ & $\begin{array}{c}\text { Standard } \\
\text { deviation }\end{array}$ \\
\hline 0 & 811 & 26 \\
\hline 1 & 1006 & 28 \\
\hline 2 & 1057 & 29 \\
\hline 8 & 1116 & 28 \\
\hline 50 & 1346 & 25 \\
\hline 100 & 1596 & 29 \\
\hline
\end{tabular}




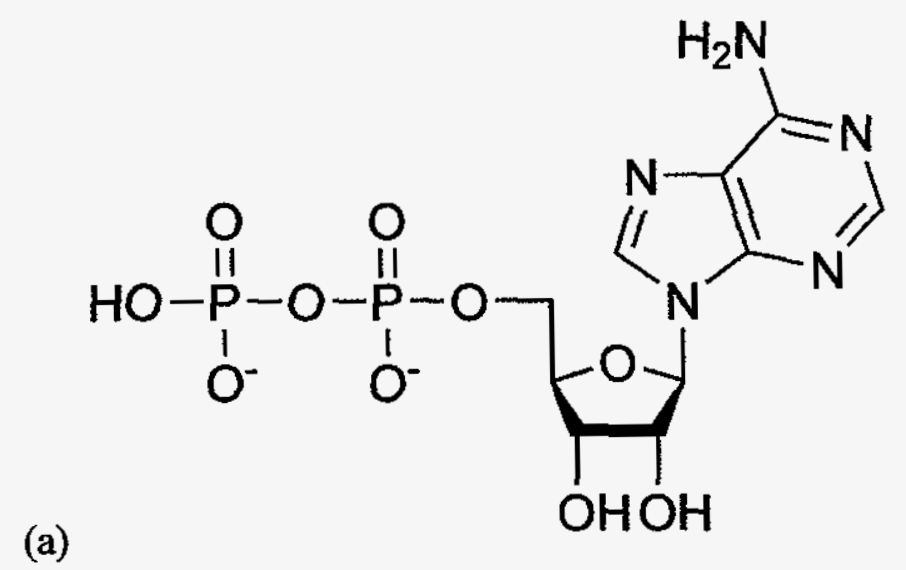

(b)

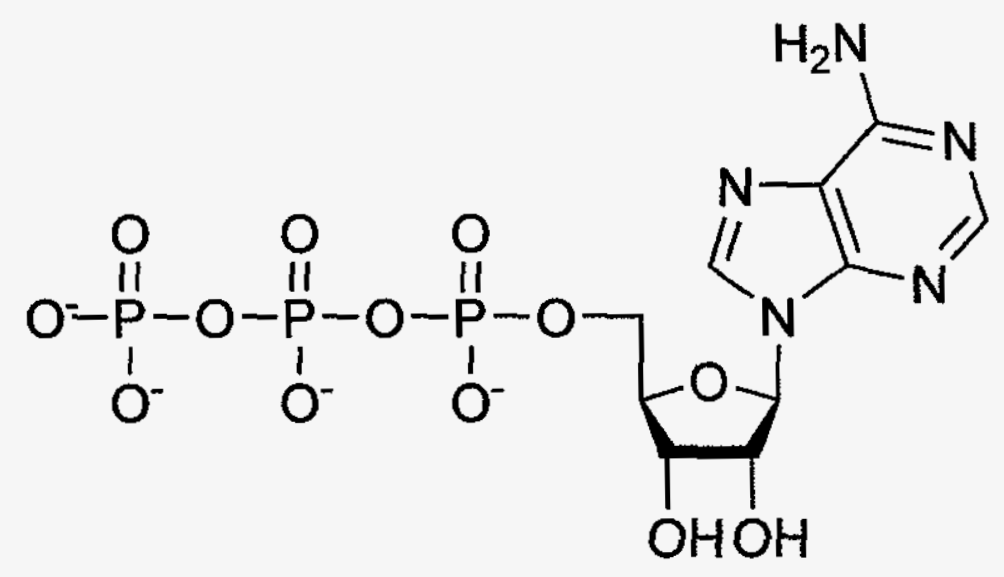

Figure 1. Chemical structures of (a) ADP and (b) ATP. 


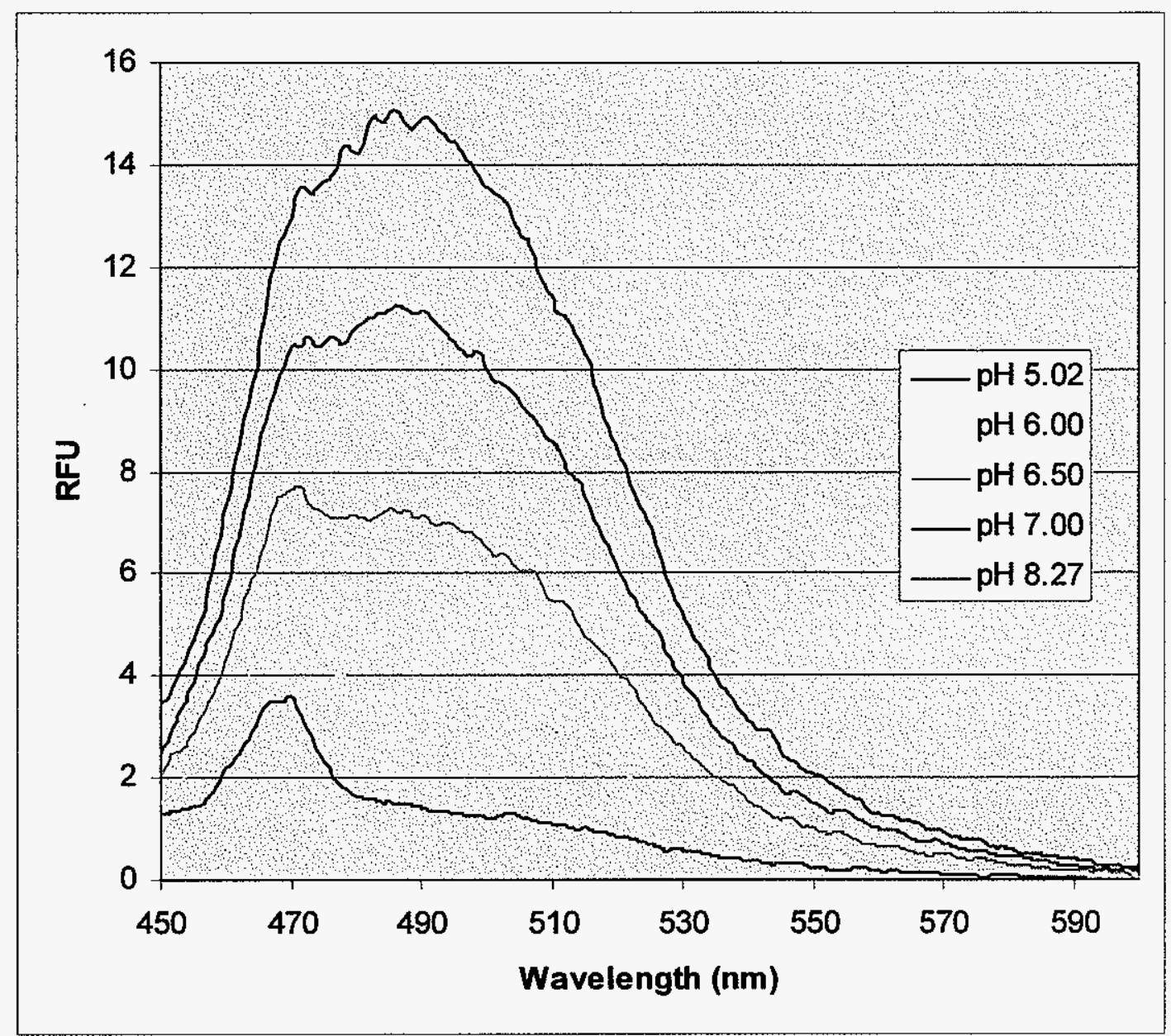

Figure 2. Emission spectra of $10 \mathrm{mM}$ ADP solutions at various pHs. Excitation wavelength: $405 \mathrm{~nm}$; [HEPES] $=10 \mathrm{mM}$; [EDTA] $=50 \mathrm{mM}$. RFU = relative fluorescence intensity. 


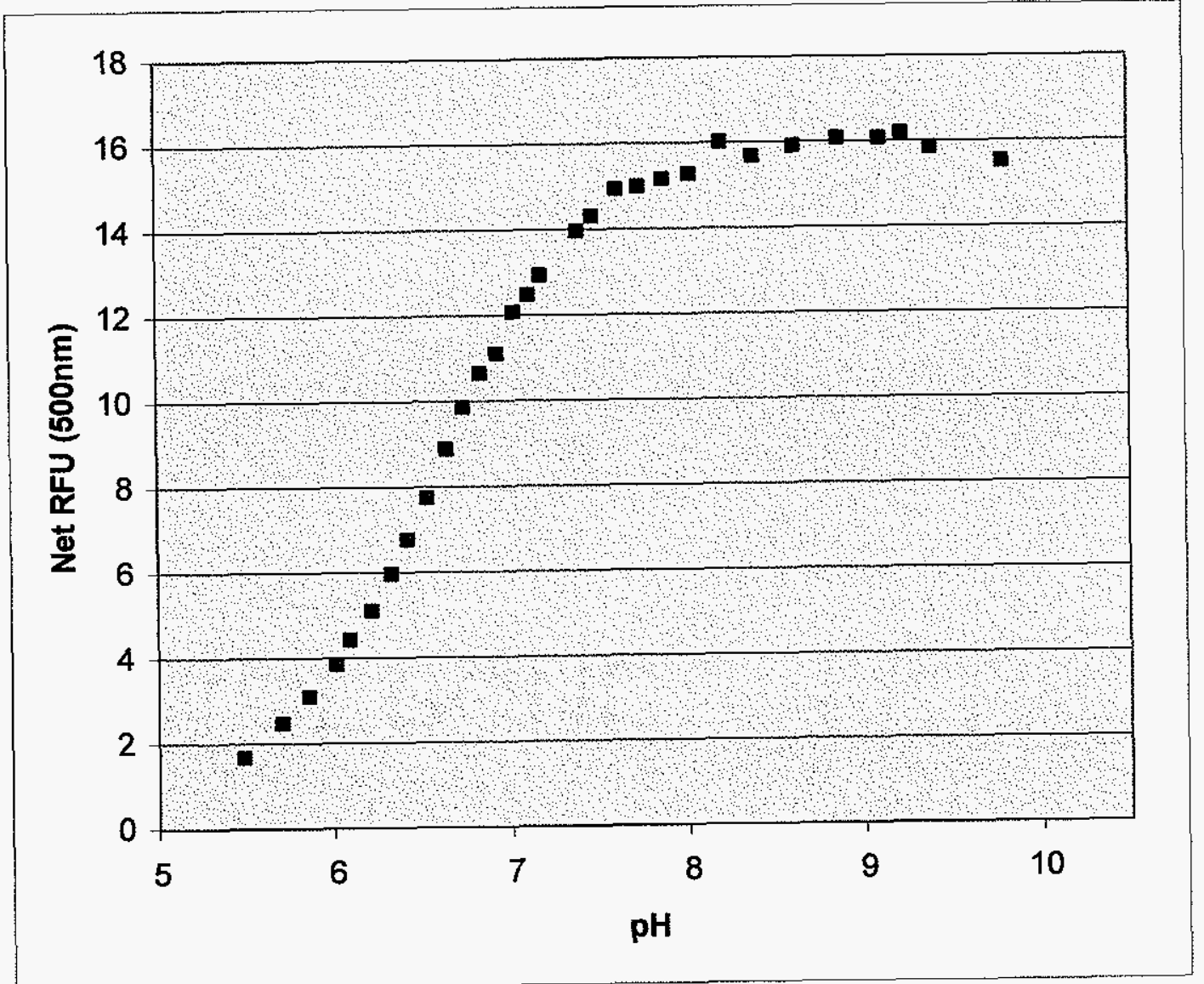

Figure 3. Net emission intensities at $500 \mathrm{~nm}$ of $10 \mathrm{mM}$ ADP vs. pH. All solutions contained $10 \mathrm{mM}$ HEPES and $50 \mathrm{mM}$ EDTA. $2 \mathrm{M} \mathrm{NaOH}$ was used to adjust solution pH. Excitation wavelength: $405 \mathrm{~nm}$. Net signal = experimental signal - background signal. Background signal is $0.48 \mathrm{RFU}$ for $10 \mathrm{mM}$ HEPES and $50 \mathrm{mM}$ EDTA at all pHs. RFU = relative fluorescence intensity. 


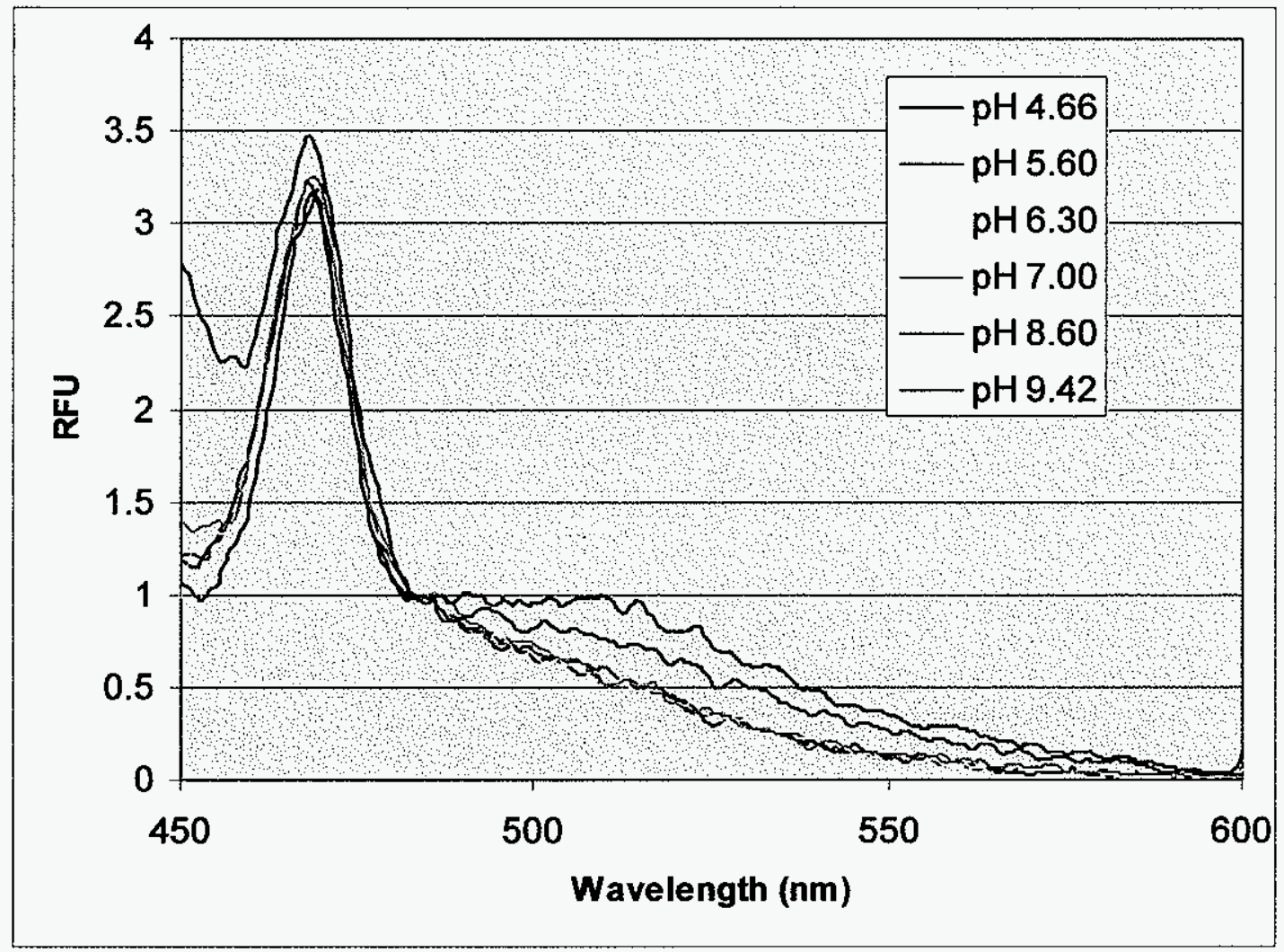

Figure 4. Emission spectra of ATP solutions at different pHs. Excitation wavelength: 405 nm. All solution contained $10 \mathrm{mM}$ ATP, $10 \mathrm{mM}$ HEPES, and $50 \mathrm{mM}$ EDTA. $2 \mathrm{M} \mathrm{NaOH}$ was used to adjust solution $\mathrm{pHs}$. 


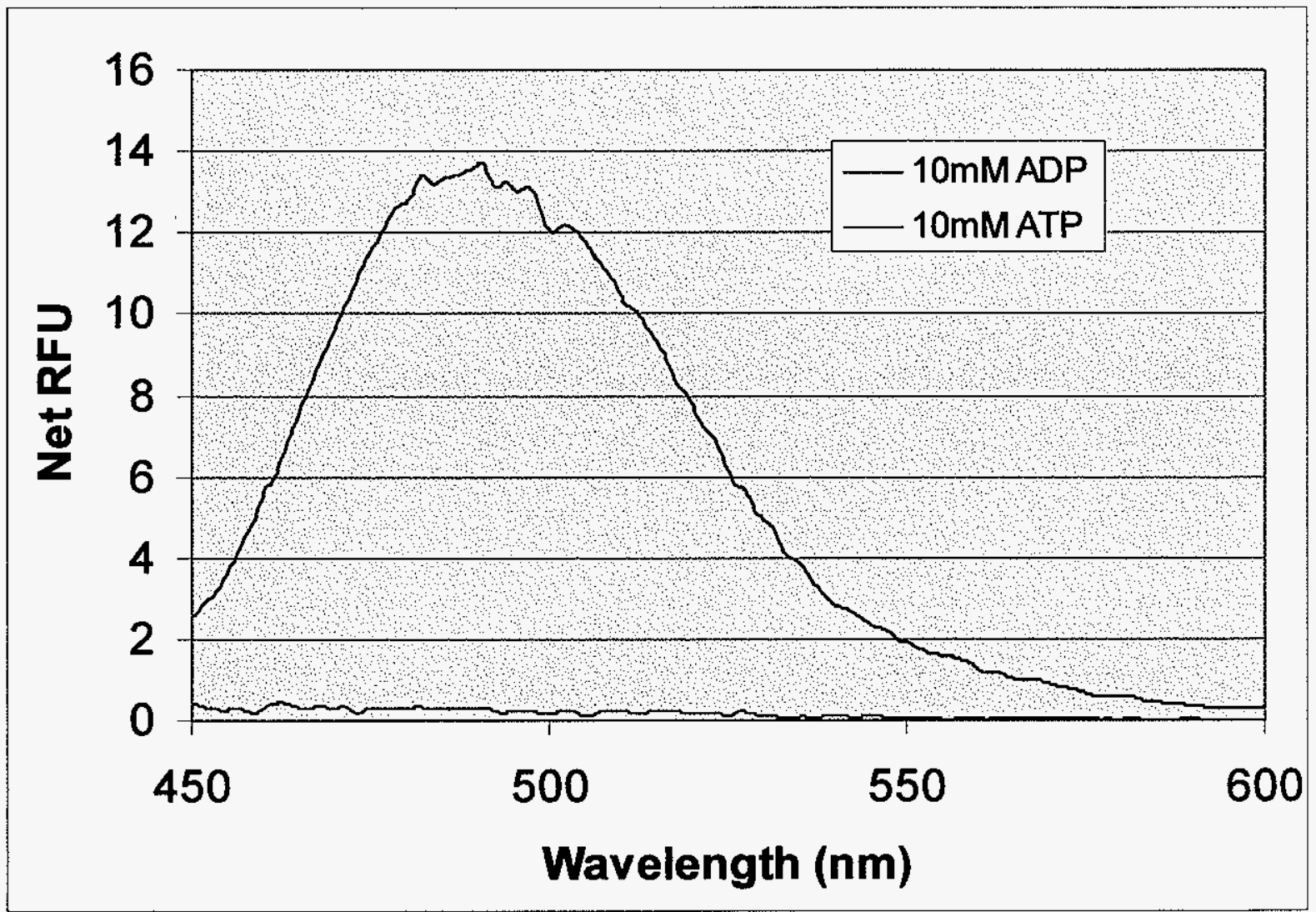

Figure 5. Comparison of emission spectra of ADP and ATP. Both solution contained $10 \mathrm{mM}$ HEPES, $50 \mathrm{mM}$ EDTA, and $10 \mathrm{mM}$ ADP or ATP. $\mathrm{pH}=8$; Excitation wavelength: $405 \mathrm{~nm}$. $\mathrm{RFU}=$ relative fluorescence unit. 


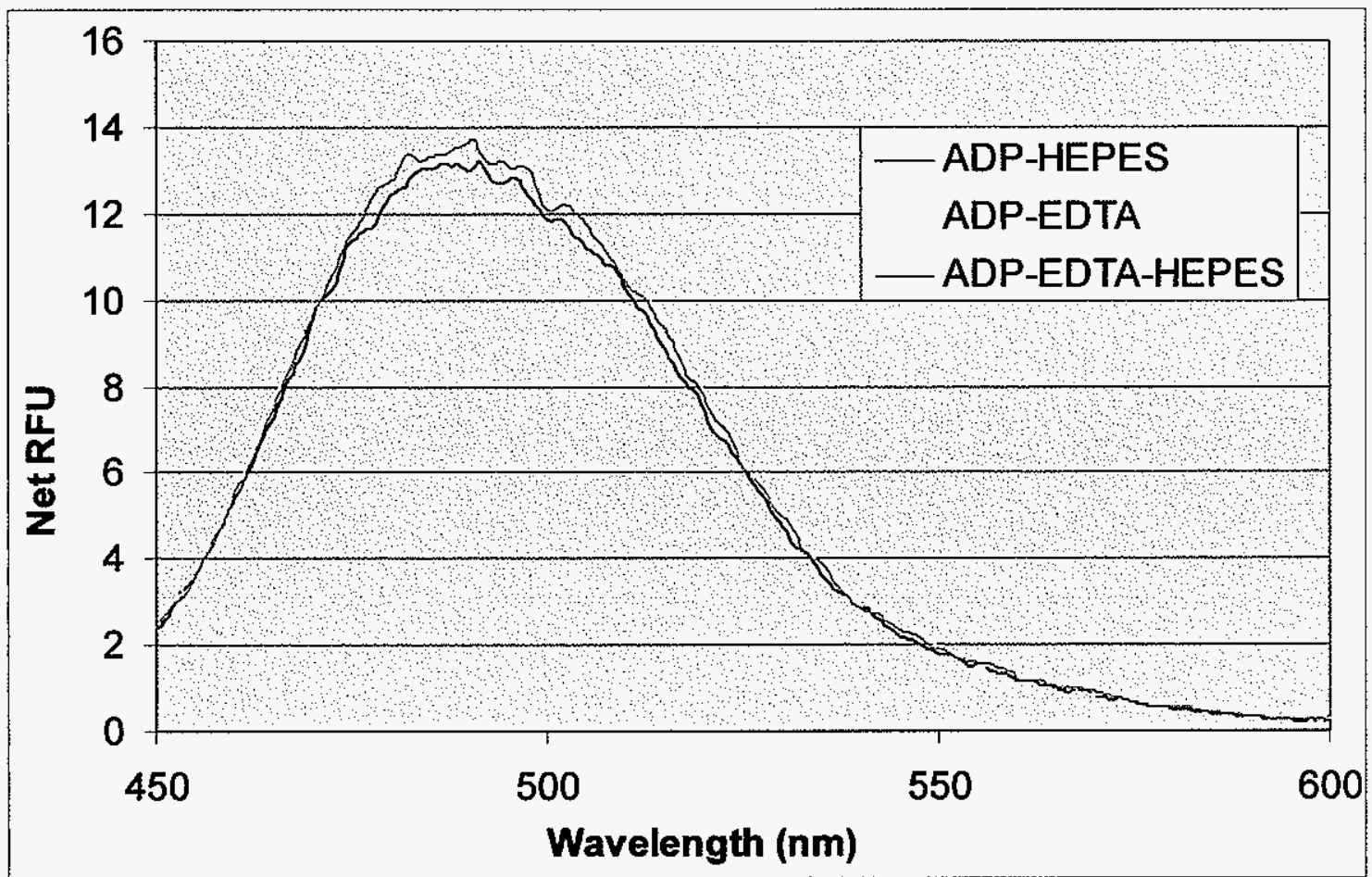

Figure 6. Net emission spectra of ADP in different buffer solutions. Solution contents are as labeled in the figure. $[\mathrm{ADP}]=10 \mathrm{mM}, \mathrm{pH}=8$ for all three solutions. Excitation wavelength: $405 \mathrm{~nm} .[\mathrm{HEPES}]=10 \mathrm{mM},[\mathrm{EDTA}]=50 \mathrm{mM}$ when applicable. Net signal $=$ signal of ADP sample - signal of corresponding background. RFU = relative fluorescence unit. 


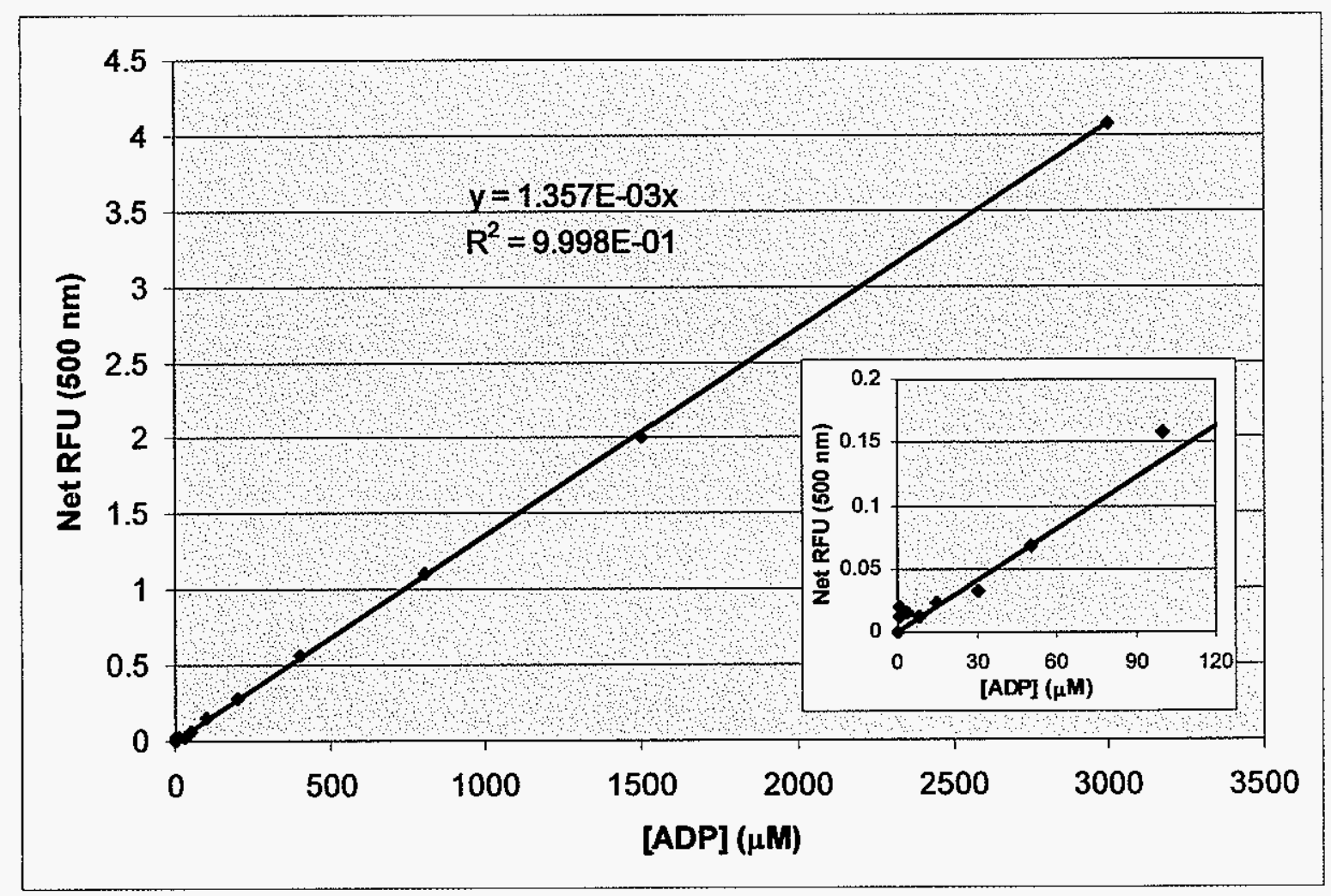

Figure 7. Standard curve of ADP solutions using fluorescence spectrometer. Excitation wavelength: $405 \mathrm{~nm} . \mathrm{pH}=8 ;[\mathrm{ATP}]=1 \mathrm{mM} ;[\mathrm{HEPES}]=10 \mathrm{mM}$. Net signal $=$ signal of ADP sample at $500 \mathrm{~nm}-$ signal of $1 \mathrm{mM}$ ATP in $10 \mathrm{mM}$ HEPES at $500 \mathrm{~nm}(0.157 \pm 0.01$ RFU). Standard deviation of background signal was $0.01 \mathrm{RFU}(\mathrm{n}=4)$. $\mathrm{RFU}=$ relative fluorescence unit. 


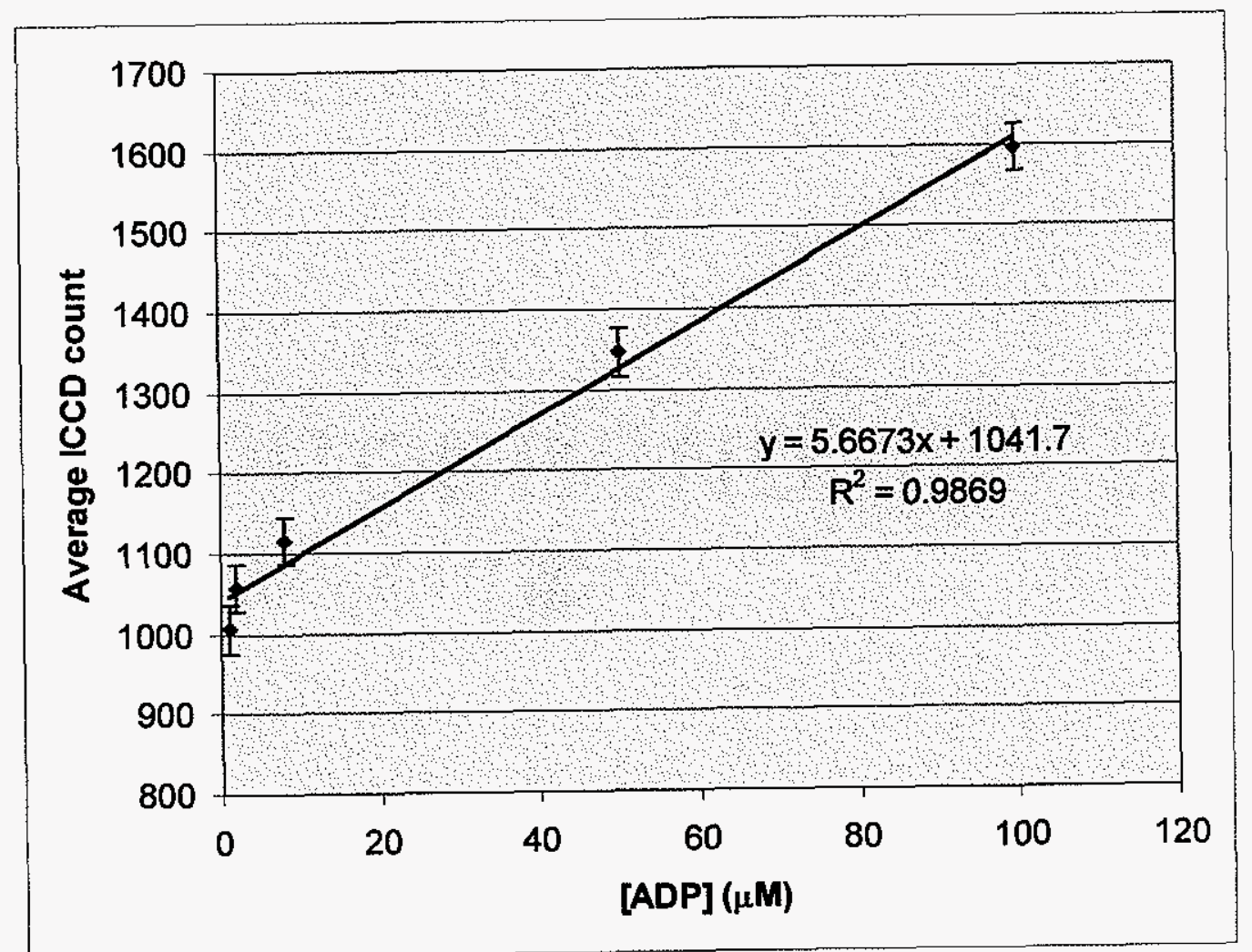

Figure 8. Standard curve of ADP solutions using ICCD. Excitation wavelength: $405 \mathrm{~nm}$. pH $=8 ;[\mathrm{ATP}]=1 \mathrm{mM} ;[\mathrm{HEPES}]=10 \mathrm{mM}$. Data shown are mean \pm standard deviation $(\mathrm{n}=40)$. 


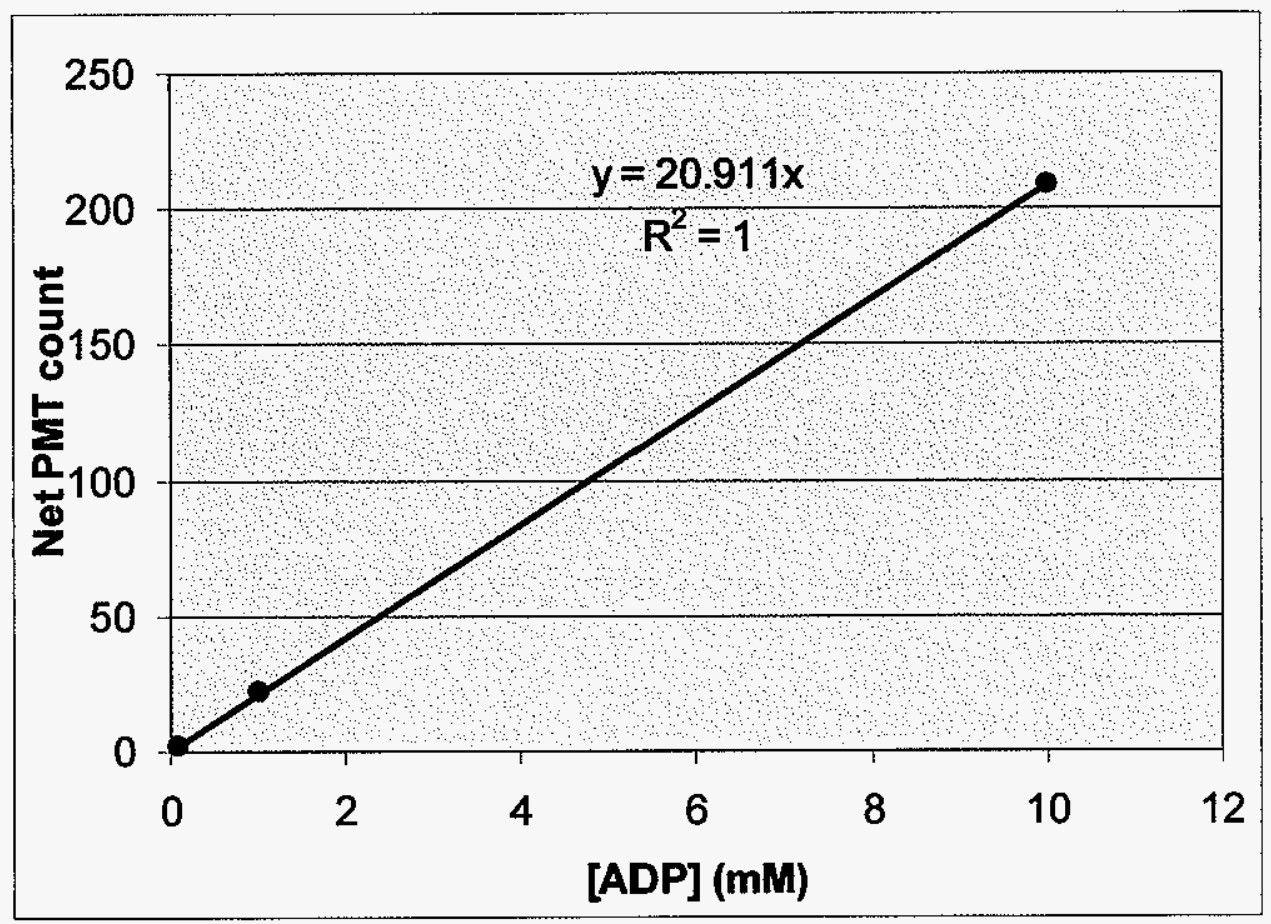

Figure 9. ADP standard curve using CE detection system. Excitation wavelength: $405 \mathrm{~nm}$. $\mathrm{pH}=8 ;[\mathrm{ATP}]=1 \mathrm{mM} ;[\mathrm{HEPES}]=10 \mathrm{mM}$. Standard deviation $(\mathrm{SD})$ of buffer solution: 0.025 counts. $3 \times \mathrm{SD}=0.075$ counts $=0.0036 \mathrm{mM} \mathrm{ADP}=$ detection limit of $\mathrm{ADP}$. 


\section{GENERAL CONCLUSIONS}

High-throughput screening (HTS) techniques have been applied to many research fields nowadays. Robot microarray printing technique and automation microtiter handling technique allows HTS performing in both heterogeneous and homogeneous formats, with minimal sample required for each assay element. In this dissertation, new HTS techniques for enzyme activity analysis were developed.

First, patterns of immobilized enzyme on nylon screen were detected by multiplexed capillary system. The imaging resolution is limited by the outer diameter of the capillaries. In order to get finer images, capillaries with smaller outer diameters can be used to form the imaging probe. Application of capillary electrophoresis allows separation of the product from the substrate in the reaction mixture, so that the product doesn't have to have different optical properties with the substrate. UV absorption detection allows almost universal detection for organic molecules. Thus, no modifications of either the substrate or the product molecules are necessary. This technique has the potential to be used in screening of local distribution variations of specific bio-molecules in a tissue or in screening of multiple immobilized catalysts.

Another high-throughput screening technique is developed by directly monitoring the light intensity of the immobilized-catalyst surface using a scientific charge-coupled device (CCD). Briefly, the surface of enzyme microarray is focused onto a scientific CCD using an objective lens. By carefully choosing the detection wavelength, generation of product on an enzyme spot can be seen by the CCD. Analyzing the light intensity change over time on an enzyme spot can give information of reaction rate. The same microarray can be used for many times. 
Thus, high-throughput kinetic studies of hundreds of catalytic reactions are made possible.

At last, we studied the fluorescence emission spectra of ADP and obtained the detection limits for ADP under three different detection modes. The detection limits are 22, 15, and 3.6 $\mu \mathrm{M}$ ADP for using fluorometer, ICCD and PMT respectively. The Michealis constant $\mathrm{K}_{\mathrm{m}}(\mathrm{AT}$ P) for protein kinases ranges from 5 to $100 \mu \mathrm{M}$. For inhibitor screening, in order to get the m ost accurate result, ATP concentration should be closed to $\mathrm{K}_{\mathrm{m}}$. In this case, further lower the detection limit of ADP is needed before the direct detection of ADP can be actually used in kinase inhibitor screening. 


\section{ACKNOWLEDGEMENTS}

First of all, I would like to thank my thesis advisor, Dr. Yeung, for his support and guidance over the past few years. Working with Dr. Yeung has been a very rewarding experience. He is an understanding and caring advisor. It has been a blessing for me to work with him in my graduate years. I would like to thank my thesis committee members, Dr. Houk and Dr. Zhao for their generous help.

I would like to collectively thank the Yeung group for making our laboratory a great working environment. Dr. Ji-young Lee has been a great labmate and friend who is always willing to help. I would also like to thank Mr. Aoshuang Xu, Mr. Hui Zhang, Dr. Hung-Wing Li, Dr. Chanan Sluszny, Dr. Yan He, Dr. Dragan Isailovic, Dr. Jinjian Zheng, Dr. Fenglei Li, Mr. Michael Christodoulou, Ms. Slavica Isailovic, Mr. Sangwon Cha, Mr. Bob Hsin, Dr. Jason Gruenhagen, Dr. Wenwan Zhong, Ms. Jiangwei Li, Ms. Yun Zhang, Dr. Ning Fang, Ms. Wenjun Xie, and Mr. Wei Sun. I gratefully appreciate their many valuable suggestions and help throughout my years at Iowa State University. I also thank Ms. Vicki Johnson for her assistance.

I would like to thank my patents for their patience, love, and support throughout my life. Finally, I would like to thank my husband and my daughter. This thesis certainly would not have been possible without their love and encouragement.

This work was performed at Ames Laboratory under Contract No. DE-AC02-07CH11358 with the U.S. Department of Energy. The United States government has assigned the DOE Report number IS-T 2294 to this thesis. 